\title{
SPOR ETIKA - GRAĐANSKA PRAVA I PRAVNI POLOŽAJ VJERSKIH ZAJEDNICA U PLURALN(ISTIČK)OM DRUŠTVU
}

$U D K: 261.6 / .7: 34$

Primljeno: 10. 04. 2018.

Pregledni znanstveni rad

\begin{abstract}
Rad razmatra odnos ustavnih orijentira s ugovorom države i vjerskih zajednica kroz tezu: država koja svojim ustavom štiti pluraln(ističn)ost društva, slobodu uvjerenja i savjesti građana i od svojih institucija i ingerencija odvaja vjerske zajednice, ne bi smjela s njima ugovarati model suradnje koji narušava ili podređuje dio ustavom jamčenih prava. Iniciranjem javne rasprave nastoji se pridonijeti razjašnjenju ne/utemeljenosti dileme o mogućem narušavanju prava čovjeka prouzročenog prekoračenjem ustava pravnim položajem vjerskih zajednica. Paradoks je ako ugovor države i vjerskih zajednica naruši humanističku etiku i laičku smjernicu jer se interpretaciji jedne etičke doktrine osobnosti čovjeka otvara više mogućnosti legalne involucije dijela temeljnih i građanskih prava. Takav ugovor ukazuje i na inkompatibilnost ustava s utilitarizmom suupravljačkog nezamjeranja.
\end{abstract}

Ključne riječi: (de)etatizacija, državna / lokalna javna sfera, laičnost, opće (ne)korisno, privatna javna sfera, supsidijarnost, sinergija, pravo izbora

\section{UVOD}

Odnosi države i religije od prosvjetiteljstva zaokupljaju pozornost društva koje se esencijalno razvijalo na humanizmu s ciljem zaštite temeljnih i građanskih prava čovjeka od vlastitih mu slabosti. Ljudi različito doživljavaju drugog i drugačije što ukazuje i na različite sustave vrednota. U zaštiti temeljnih prava dostojanstva, jednakosti i ravnopravnosti ljudi ${ }^{1}$ suvremena država ima kulturnu i antropološku pretpostavku, a u liberalnoj pluraln(ističk)oj demokraciji organizacijsku posljedicu. ${ }^{2}$

* damir.bulat@skole.hr

1 Deklaracija UN-a o pravima čovjeka, čl. 1. (3. travnja 2008.), http://www.amnesty.hr/stranica. php?sifra_str=opca_deklaracija; Peter Häberle, „Ljudsko dostojanstvo i pluralistička demokracija“, Politička misao (4⿳亠丷厂) 2 (usp. G. Dürig), 2006., str. 15-16/22; Ideje o jednakosti, zaštiti dostojanstva i ravnopravnosti ljudi zametke imaju u blisko vrijeme (6.-5. st. pr. n. e.) na tri geografski disperzirana prostora: u Indiji pojavom budizma, u Kini Konfucijevim učenjem i u starih Grka. Izvor i svrha viđeni su u ljudskom duhu. Kršćanstvo ih je intenziviralo i pripisalo Bogu. Oživljavanjem ljudskog duha u doba prosvjetiteljstva i neki europski monarsi skromno su nastojali zaštititi te supstance o poimanju čovjeka i društva.

2 Usp. Peter Häberle, „Ustav kao kultura“, Politička misao (37) 3, 2000., str. 4; Dragica Vujadinović, „Civilno društvo i politička kultura“, Filozofska istraživanja (28) 1, 2008., str. 25. 
Damir Bulat: Spor etika - građanska prava i pravni položaj vjerskih zajednica u pluraln(ističk)om... Zbornik radova Pravnog fakulteta u Splitu, god. 55, 3/2018., str. 639.- 665.

Stoga ustavi ukazuju na distinkciju privatne javne i državne / lokalne javne sfere. Pozicije vjerskih skupina zakonski su jednake, a njihove ovlasti su odvojene od državnih / lokalnih jer su potonje obveza svih građana. ${ }^{3}$ Europska unija poštuje status vjerskih grupa po zakonima članica pa je praksa tih odnosa različita ovisno o državi. To znači da oni i nisu bitno ${ }^{4}$ pitanje Europske unije što vjerskim grupama, na temelju statistike i nacionalne povijesti, pruža i privilegiran status. ${ }^{5}$ No, kako u pluraln(ističk)om društvu privatne i religijske akcije ulaze i u državnu / lokalnu javnu sferu, to potiče i dilemu o mogućem narušavanju dijela ustavnih prava građana. Tu sumnju snaži i van (ili nad?) - ustavni status javne pravne osobnosti vjerske zajednice jer ima snagu javnog zakona. ${ }^{6}$ To izražava nesklad s ustavnom ravnopravnosti građana jer ih ne lišava obveze. ${ }^{7}$ Kontroverze tih odnosa nameću pitanje: Što su prava vjerskih skupina, a što prava i obveze države, jamca ustavnih normi $?^{8}$ Ono je važno zbog distinkcije državnog (obvezujućeg) i privatnog (neobvezujućeg) na javnoj razini. Ta razlika, po ustavu, treba utjecati na sadržaj ugovora države i religije. ${ }^{9}$ Država ne smije favorizirati agnosticizam, ateizam ili teizam jer su subjektivizam i etički emotivizam esencijalni za egzistenciju uvjerenja, savjesti. Usmjeravanje religije na privatnu javnu sferu gdje se prožimlju ta (ne/ točna, ne/opravdana) uvjerenja i akcije jest u čimbeniku vremena, a i u teološkim

3 Ustav RH, čl. 22., 35., 40. i 41., Narodne novine, IX. izdanje, 2005.; Ugovor ... o pravnim pitanjma, čl. 1., Ugovori Svete Stolice i RH, Glas koncila, Zagreb, 2001.; Henri Pena Ruiz, „Što je laičnost", Politička kultura, Zagreb, 2004., str. 22/25/77/101.

4 Europska unija, prvenstveno kao ekonomska integracija, razvijala se na principu funkcionalnosti s ciljem zajedničkog iznalaženja odgovora država članica i same Unije oko kojih je moguć konsenzus. Kultura i odnos prema religiji prepušteni su državama članicama. Ne toliko zbog marginaliziranja te problematike, koliko zbog velikih razlika unutar država članica i tradicionalne vezanosti za pojedine režime odnosa prema religiji. Sličan je pristup Unija zauzela prema udrugama civilnog sektora. Iako je bilo inicijativa da se u pogledu religije donesu pravni akti koji bi se primjenjivali na razini Unije (npr. Toledo guiding principles OESS-a iz 2007.), od toga se (za sada) odustalo zbog, očito nepomirljivih, razlika među državama članicama. Slično tome, ni Europski sud za ljudska prava ne preispituje odnos države i vjerskih zajednica, već samo pojedine slučajeve koji dođu pred sud (npr. vjerski simboli u školama...). Vjerojatno zbog oportunog pristupa 'ne drži se pozvanim miješati' u postojeća rješenja čija bi sudbina (u konačnici) ovisila (isključivo) o volji većine u političkoj zajednici u kojoj takvi (različiti) pristupi postoje.

5 Rik Torfs, „Religion and State Relationships in Europe”, Religious Studies Review (1) 4, 2007. str. 31-34/38. Rereligizacija državnih javnih institucija i ingerencija u većem dijelu postkomunističkih država odvijala se zapostavljanjem 'prava izbora' građana. Očito i s ciljem da vjerske zajednice ubrzano i obimno 'nadoknade' zastoj iz totalitarnog perioda.

6 Ugovor ... o pravnim pitanjima, čl. 2/1.; Ustav RH, čl. 140.; usp. Frane Staničić, „The legal status of religious communities in Croatien law", Zbornik PFZ, 64 (2) 2014., str. 242; Alan Uzelac, „Od liberalizma do katolicizma: neki aspekti reguliranja pravnih odnosa između crkve i države u RH novo pravno uređenje braka“, u: Liberalizam i katolicizam u Hrvatskoj, II, Friedrich-Naumann-Stiftung, Zagreb, 1999. (usp. M. Lanović: teorije jedinstva i koordinacije crkve i države suprotne su sustavu laičke države), str. 517; Hrvoje Špehar, „Prototipski slučaj francuskog modela laičke republike. Da li je 'izvoziv' unutar EU?"“, Godišnjak, 3/3., 2009., Univerzitet Beograd (FPN), 'kooperacijski model ... ne može se formirati na dosljedno provedenoj jednakosti svih građana', str. 286.

7 Usp. Špehar, 'ideja ravnopravnih građana nasuprot ideji komunitarnih prava', 2009., str. 277-278; Pena-Ruiz, 'o razlici pojmova društvo i zajednica', str. 141-142.

8 Usp. Carmen Lopez Alonso, „Laičnost ili odvajanje države od religije u zapadnoj europskoj tradiciji”, u: Religija i sekularna država, Međureligijski institut BiH, Sarajevo, 2007., str. 50.

9 Häberle, 2000., str. 9; Komparacija čl. 3., 14., 16., 40., 41. i 140. Ustava RH. 
spoznajama koji izvor vjerske etike i duha vide u osobnom zaokretu čovjeka. Stoga je u modernosti otvoren prostor civilnom društvu koje i religijskim skupinama pruža neprisilne javne akcije. ${ }^{10}$ No, i civilnost nudi slabosti, zlouporabe i idealizaciju (ideologizaciju); neodređenost kao legitimitet trajnom djelovanju. ${ }^{11}$ Zato $\mathrm{u}$ definiranju civilnog kao nepolitičkog društva koje teži povećati učinkovitost vlasti i pokrenuti socijalni kapital s ciljem poboljšanja odnosa u najdemokratskoj maniri, važno je razlučiti namjeru i karakter tih akcija ${ }^{12}$ na: osobne / privatne, društvu nekorisne; i općekorisne koje supsidijarno (kontoliranom deprivatizacijom) ulaze u sferu državnih / lokalnih javnih ovlasti. ${ }^{13}$ Implementacija supsidijarnosti ukazuje da laičnost ${ }^{14}$ privatnim a društvu korisnim akcijama otvara prohodniju, etički manje spornu, a pravno kvalitetniju, suradnju s državom.

Etika suvremenog društva oslanja se i na humanizmu kompatibilnim religioznim vrednotama u poimanju čovjeka pa religija u pluraln(ističk)om okružju ima (in) formativnu ulogu. Iako se pripadnost iskazuje osobnim izborom, ona i za građane laičkog poimanja države ima relevanciju..$^{15}$ Pozitivni udio religije u kulturnom stvaranju dio je identiteta koji eksplicira javnu zaštitu. Modernitet uvažava taj prinos jer generira neprisilnost i koheziju, te isključuje totalitarne tenzije prema religijskom. ${ }^{16}$ No, javna zaštita isključuje (političku, vjersku...) ideologizaciju i manipulaciju identitetom. ${ }^{17}$ Zato se laičnost ne može tretirati isključivom, ni po

10 Siniša Zrinščak, „Religija, civilno društvo, socijalni problemi“, Društvena istraživanja (75-76) 1-2, 2005., str. 82/90.

11 Walter Reese-Schafer, „Civilno društvo i demokracija“, Politička misao, 41 (3), 2004., str. 66; Ante Pažanin, „Pravednost i civilno društvo“, Politička misao (40) 2, 2003., str. 12-13; Vujadinović, str. 23.

12 Usp. Reese-Schafer (usp. C. Montesquie i J. Habermas), str. 67/70/74.

13 Zrinščak (usp. J. Casanova), 2005., str. 82; usp. Vujadinović, str. 28. Supsidijarnost državu depaternalizira, a društvo demokratizira. Rimokatolička crkva uvela je načelo supsidijarnosti u socijalni nauk da dio svojih akcija izjednači s državnim, a da država pritom ne izgubi legalitet i legitimitet. No, zakonom bi trebalo razlučiti i precizirati narav privatnih javnih akcija u svrhu zaštite prava $i$ obveza svakog čovjeka - najnižeg supsidiariusa, esencijalno i egzistentno opće dobro.

14 O razlici pojmovima laičnost i sekularizacija vidi Hrvoje Špehar, „Laičnost: etimologija i historijat", Politička misao (48) 1, 2011. (usp. J. P. Schreiber), str. 128-130.

15 Špehar (usp. E. Poulata), 2011., str. 129.

16 Usp. Dino Abazović, ,Sekularizam i sekularizacija u sadašnjem javnom diskursu - iz ne-religijske perspektive", u: Religija i sekularna država, Međureligijski institut BiH Sarajevo, 2007., str. 191; PenaRuiz, str. 29.

17 Marino Ninčević, „Interkulturalizam u odgoju i obrazovanju“, Nova prisutnost (7) 1, 2009., str. 62. Religijski simboli dio su identiteta. No, njihova upotreba u javnim institucijama ne bi smjela poticati vjersku nadmenost i narušavati ustav (v. Norberto Bobbio, Liberalizam i demokracija, Novi Liber, usp. T. Paine, 1992., str. 19-20) koji ima dvojaku namjenu zaštite:

a) baštinsko, identitetsko značenje tih simbola (v. de Mattei (usp. J. H. Weiler), str. 63-64); Ustav RH, čl. 14., 40. i 41. štiti i pomaže vjerske vrednote kao dio identiteta i narodne kulture; usp. Mladen Labus, „Vrijednosti u hrvatskom društvu“, Sociologija sela, 38, 1-2 (2000.), str. 165);

b) različitosti građana jer su vjerski simboli vezani i za osobnu potrebu od koje javni zakon apstinira. Po čl. 11/3. Ustava RH i Zakonu o zastavi, grbu i himni RH i lenti predsjednika RH, javnim institucijama vjerski simboli nisu obvezni, http://narodne-novine.nn.hr/clanci/sluzbeni/253505.html, 9. srpnja 2010. No, Zakon o izboru predsjednika RH (1997.), čl. 4/3., nedvosmisleno izražava obvezu religijske opcije, http://www.poslovna.hr/zakoni/public/zakoni.aspx?zakon=Zakon-o-izboru-predsjednika-RepublikeHrvatske-\%E2\%80\%93-iz-1997.-godine\&id=14172, 9. srpnja 2010.); usp. Matija Miloš, „Sloboda 
formi, ni po sadržaju. ${ }^{18}$ I obimni negativni historijat etatizacije religije generirao je legalno krnjenje dostojanstva, jednakosti i ravnopravnosti čovjeka ukazujući i na raskorake izjavnog i življenog. To je iz doba prosvjetiteljstva (niklog u kršćanskom okružju) bio uzrok laičke norme. ${ }^{19}$ Kao mentalni iskorak evoluirala je zakonska ravnopravnost ljudi (zapostavljana od religioznih i svjetovnih vlasti) kao temelj humanizma. ${ }^{20}$ Statistika utječe i na akcije vjerskih zajednica i na odnose u društvu, no, kako postoje razlike u sustavu vrednota u svjetovnijim i religioznijim društvima, ${ }^{21}$ još izraženije kod pojedinca i skupina, ne bi se smjela narušiti državna /lokalna javna razina.

\section{RELATIVIZACIJA ILI DEMISTIFIKACIJA I HUMANIZACIJA 'KONAČNIH' ISTINA?}

Svako se društvo temelji na vrijednostima svog kulturnog stanja, s mogućnošću implikacija ideoloških naslaga tog vremena. Suvremena legislativa, odraz evolucije svijesti i savjesti iz kojih vrednote proizlaze, usmjerena je dezideologizaciji i etički prihvatljivoj diferenciranoj populaciji pluraln(ističk)og društva. Ona štiti naslijeđene i stvarane vrijednosti, simbole i ideale, što negira favoriziranje, podređenost ili isključivost jednih od drugih.

'Ljudski zakoni moraju se podrediti Božjima.'22 Vjerska slika, uz sve manjkavosti, tretira se civilizacijskom vrednotom jer je protkana i pozitivnim a čovjeku manje ili više shvatljivim smjernicama. Iako razlikuju privatnu religioznu ${ }^{23}$ od državne razine, ${ }^{24}$ vjerski lideri opravdano ističu da se religioznim građanima ne smije uskratiti pravo da u politici o pitanjima općeg dobra djeluju po vlastitoj savjesti. ${ }^{25}$

isticanja vjerskih simbola u svjetlu odvojenosti vjerskih organizacija od države“, Zbornik PFZ, 61, 1 (2011.), 'Ako se država svrsta uz određeni simbol, potencira nove konflikte...', str. 188); Špehar, 2009. str. 286. Opaska raspravi u RH od 2009. g. o (ne)postavljanju vjerskih simbola u javnim institucijama: 'Primjerenije i duhovnije je vjerski simbol držati na javnom radnom stolu okrenutom prema sebi, da olakša teškoće tijekom rada. Nametljivo i upadno na zidu iza leđa služi da ga se vidi tek kad netko uđe.', Usp. Biblija, Kršćanska sadašnjost, Zagreb, 1991., Mt., 6, 5-8; Miloš, str. 192-194.

18 Usp. Srđan Vrcan, „Europski identitet - neke ključne dileme“, Revija za sociologiju (36) 1-2, 2005., str. 15-16; Milan Polić, „Odgoj i pluralizam“, Filozofska istraživanja (26) 1, 2006., str. 34.

19 Usp. Claus Offe, „Tocqueville, Weber i Adorno u Americi. Hoće li se Europa amerikanizirati?“, Politička misao, Zagreb, 2004, str. 26.

20 Usp. Jacques Maritain, Čovjek i država, Globus, Zagreb, 1992., str. 156.

21 Usp. Ivan Markešić, „Religijska situacija u postmodernom vremenu“, Društvena istraživanja (7576) 1-2, 2005., str. 105 .

22 Usp. Tonči Matulić, „Jednakost i nediskriminacija: Vrijednosna polazišta u suzbijanju diskriminacije“",Zbornik PFZ, (59) 1, 2009., str. 19/22; Marcelo Pera, Zašto se trebamo zvati kršćanima, Liberalizam - Europa - Etika, Verbum, Split, 2009., str. 107; de Mattei, str. 114.

23 Usp. Grubišić, o razlici pojmova religijsko i religiozno (1991., 76).

24 Mato Zovkić, „Katoličko gledanje na religije u zemljama tranzicije“, u: Religija i sekularna država, Međureligijski institut BiH, Sarajevo, 2007., str. 39-40.

25 Joseph Ratzinger, Tarcisio Bertone, „Doctrinal note on some questions regarding the participation of Catholics in political life“, 2003., str. 6., http://www.ewtn.com/library/curia/cdfpolif.htm, 2. ožujka 
Kler ima obvezu po profesiji i ljudsko pravo da javnim iskazom upozori i animira o životnim izazovima i zamkama, te kritički mobilizira javnos ${ }^{26}$ jer je i religioznost dio etičke svijesti i savjesti pa i njezino razmišljanje stremi općem obrascu. Stoga im zagovaratelji laičke države ne smiju osporiti da u javnoj raspravi daju obol intencirajući svetu mogućnost istinitog. ${ }^{27}$ No religiozni zahtjevi upućeni državnoj vlasti imaju za cilj da ta etika (ili njezin dio) postane i obveza pluraln(ističk)om društvu. Ima li ona pokriće? Ima. Iz najmanje dva razloga:

- javno iznošenje stavova kao vid građanskog neposluha prema postojećoj legislativi, tj. prijedlog drugačije kvalitete uređenja pravnih normi, dio je demokratske lepeze;

- vjerska slika primarno ovisi o Bogu, stoga nije podložna povijesnom prevladavanju prema racionalnim kriterijima modernog društva. ${ }^{28}$

Kroz prošlost upravljanja, liberalno-demokratski koncept (uz svu opravdanost kritike njegovih devijacija ${ }^{29}$ dao je do sada najbolji oblik zaštite ljudskih prava i kompeticija. Prethodno je bila nužna laičnost različitih uvjerenja, tj. zaštita javnog

teizma, ateizma i agnosticizma. To priznaju i konfesionalni dokumenti. No, laičnost ne podrazumijeva otklon od morala.$^{30}$ Stoga nije važno dolazi li zahtjev za promjenom zakona od religijskog ili ireligijskog subjekta. Važan je njegov karakter. Je li moralan, pravedan? ${ }^{31}$ No, lideri vjerskih zajednica konačnim aksiomom idu za etičkim korekcijama na način da suštinski konkuriraju suvremenom ustavu ne pokazujući permisivnost prema drugom uvjerenju ni kad se ono dotiče isključivo osobnih života drugih ljudi. Kako je moral neovisan i o religioznom, ${ }^{32}$ laička humanističko liberalna tradicija iz javnih zakona isključuje vanjski i monološki utjecaj na savjest. Postojanje različitih etičkih tradicija je evidentno pa definiranje modela za detekciju moralnog kao općeg dobra ostaje (trajna) dilema.

Iniciranje etičkih normi koje ne involuiraju autonomno pravo građana u odluci o osobnom štiti ne/zahvalno uvjerenje - nadziranje vlastitosti. To je prihvatljivo i potpuno (geografskom disperziranošću i kulturnim podrijetlom) različitoj populaciji jer ima elemente desubjektiviziranog tj. odredivog u svim etičkim tradicijama. ${ }^{33}$ Nadziranje vlastitosti suštinski izražava i dostojanstvo ogledano u svom sadržaju,

2010.

${ }^{26}$ Ivica Raguž, „Poslanje Crkve u pluralizmu - preobražavajuće prihvaćanje”, Bogoslovska smotra, (73) 2-3, 2003., str. 290; Zrinščak, 2005., str. 85; Josef Stala, „Punina dostojanstva osobe - civilizacija ljubavi u kontekstu postmoderne“, Crkva u svijetu (50) 3, 2015., str. 476.

27 Abazović (usp. J. Habermas), str. 192.

28 Usp. Matulić, str. 22.

29 Ovdje je korisno sjetiti se poznate uzrečice W. Churchilla: „Demokracija je loš oblik vladavine, ali (još uvijek) ne znamo bolji."

30 Usp. Ratzinger, Bertone, str. 4-5; Pena-Ruiz, str. 23.

31 Josip Šimić, „Religije i crkve pred izazovom globalizacije“, Filozofska istraživanja (29) 4, 2009. (usp. G. Piana), str. 752-753.

32 Jovan Đorđević, „Moralno vaspitanje, religijsko vaspitanje i škola“, Nastava i vaspitanje, Beograd, (41) 4-5, 1992., str. 327; Ratzinger, Bertone, str. 4-5; Pena-Ruiz, 'o duhovnosti', str. 27.

33 Usp. Pena-Ruiz, 'laički ideal', str. 57/89/187/197. 
minimumu samointeresa spoznatljivog svakom čovjeku, tj. funkciji koja ljudima generacijski pruža dosezanje svoje prirode i potiče razvoj kulture. ${ }^{34}$ Ta bi se komponenta trebala respektirati u svim kulturama jer se ne može kulturnospecifično reducirati. ${ }^{35}$ Ona involuira svaku utopiju, a involvira realnu snošljivost različitosti koje nisu prijetnja vlastitom identitetu jer je razlikovanje od i ravnopravnost $s$ drugim ujedno i njegov jamac. ${ }^{36}$ I nadziranje vlastitog može se tretirati fenomenološki. ${ }^{37}$ Upravo da osobnim izborom poveća obvezu koju neka ide(ja/ologija) projicira na pojedinca u društvu, ili da se od njezine obveze i neodredivosti slobodovoljnim diferenciranjem definira, te okvire nude laički zakoni. ${ }^{38}$ Utoliko je sloboda i spoznata nužnost i usklađivanje života s njom, i sloboda od prinude i jamac osobnog izbora, tj. ona kao samoodređujuća djelatnost. ${ }^{39}$ Kako čovjek nije savršen, ni sloboda nije apsolutna. No, oduzimanje prirodom uvjetovane i kulturom stvarane slobode, čovjeku se negiraju pravo, odgovornost i integracija, $\mathrm{tj}$. duhovnost dostojanstva. ${ }^{40}$ Zato država i društvo ne mogu biti iznad individuuma. ${ }^{41}$

I religija demokraciju tretira kvalitetnim konceptom neposredne političke aktivnosti građana za odluke o općem dobru, tj. 'pravilnom razumijevanju digniteta ljudske osobe, zbog čega on ne smije biti izložen vanjskim utjecajima koji bi ograničili savjest $u$ traženju i prihvaćanju istinske religije' ${ }^{42}$ To znači da se do pravilnog definiranja i tretiranja digniteta osobe dolazi samo ako je savjest autonomna. ${ }^{43}$ Taj kriterij kao spoznajni put za moralan stav o osobnom ima elemente prihvatljive svim tradicijama. No, po religioznoj savjesti 'temeljne, konačne vrjednote su izvan čovjeka $i$ nisu predmet demokratskog odlučivanja i preglasavanja' ${ }^{44}$ Zato nizu religioznih lidera ne postoje jednako valjane i razumne moralne, filozofske ili ine vjerske doktrine koje nisu u skladu njihove vjere. ${ }^{45}$ To znači: religiozna etika je jedino ispravna, a egzistencija etičkog pluralizma (tj. 'svjetovne duhovnosti') jest 'kulturni i moralni relativizam koji vodi dekadenciji i dezintegraciji razuma $i$ principa prirodnog moralnog zakona' koji je jedan, a njegovo poštovanje je pitanje morala ukorijenjenog u ljudskoj naravi. ${ }^{46}$ Vrijedi za sve ljude u svakom vremenu,

34 Enes Kulenović, „Pluralistička teorija utemeljenja ljudskih prava“, Politička misao (46) 1, 2009. str. 196-198; Branko Bognar, ,Stvaralački pristup znanosti“, Metodički ogledi (15) 1, 2008., str. 19.

35 Usp. Häberle, 2006., str. 21; Pena Ruiz, str. 24.

36 Davor Rodin, „Zakašnjela sekularizacija“, Politička misao (44) 1, 2007., str. 11.

37 Usp. Häberle, 2006., str. 34.

38 Usp. Pena-Ruiz, str. 33/35.

39 Nikola Skledar, „Religijske promjene i vrijednosti“, Sociologija sela (38) 1-2, 2000., str. 18.

40 Usp. Häberle, 2006., str. 9/37.

41 Usp. Josip Grbac, „Političko-društveni vid supsidijarnosti: Teoretsko utemeljenje supsidijarnosti u društvenom i političkom životu“, Bogoslovska smotra (79) 1, 2009., str. 32; Stala (2015., 475).

42 Ratzinger, Bertone, str. 3/7.

43 Zovkić (Gaudium et spes i Papa Ivan Pavao II. 1991.), str. 39

44 Josip Baloban, „Pozicija i uloga Crkve u Srednjoj i Istočnoj Europi 20 godina nakon urušavanja komunističkog sustava“", Bogoslovska smotra (79) 4, 2009., str. 743; Ratzinger, Bertone, str. 1.

45 Enes Kulenović, „Ratzinger protiv Rawlsa: propast preklapajućega konsenzusa“, Politička misao, (40) 1, 2003., str. 38.

46 Ratzinger, Bertone, str. 2/4-5; Pera, str. 153. 
a religioznost ima moralnu dužnost da one koje vode pogrešne vrednote izvede na pravi put. ${ }^{47}$ Njezine su poruke obvezne za život svih ljudi pa je skoro nemoguće, osim 'represivno' / zakonom, od religioznih tražiti da svoj stav ograniče samo na svoj život. ${ }^{48}$

No, je li ljudska narav unificirana - jedan zakon, ili je ona kompleksna, složena? Ako je unificirana, kako objasniti i vrednovati historijat trajnosti i kvalitetu obola različitih uvjerenja, savjesti kad su svi ukorijenjeni u ljudskoj prirodi? Nije li ono što je u njoj stalno i trajno upravo kompleksnost? Da bi čovjek pravilno rasuđivao, savjest treba biti autonomna, samosvojna što ukazuje na složenost naravi, tj. potrebu ljudi da se sami odrede: vrednuju, biraju, mijenjaju, a ne da isprogramirano slijede. ${ }^{49}$ Treba li onda stvoriti 'jedan zakon ukorijenjen u naravi', ili civilizacija zbog složenosti naravi treba graditi zakone koje valja misliti s aspekta dostojanstva svakog čovjeka ${ }^{50}$ koje ne smije biti izloženo vanjskom utjecaju jer bi mu ograničilo savjest?

Religiozni lideri argument valjanosti slike prirodnog moralnog zakona izvode iz svoje doktrine po kojoj je utemeljeno i ljudsko društvo; a sebe nazivaju njegovim čuvarom..$^{51}$ Zato i religiozni građani u politici sve zemaljske aktivnosti moraju obavljati na način da ih u odluci o općem dobru vodi religiozna savjest. ${ }^{52}$ To implicira etatizaciju dogme po kojoj drugog valjanog uvjerenja (savjesti u potrazi) nema. ${ }^{53}$ Ona izvana uvjetuje pa je takvo tretiranje prirodnog morala monološko, unificirano. Uskratiti inima pravo na nadziranje vlastitosti u pitanjima općeg dobra, posebno pod presijom odanosti i neizvrgavanja opasnosti da nam članovi naše tradicije ne okrenu leđa ${ }^{54} \check{c} v$ rst je javni sklad s vlastitim. Kako u pluralizmu različite tradicije ravnopravno sužive, takav sklad ukazuje na (u negativnom smislu) ideološku narav vlastitog. ${ }^{55}$ Jesu li ljudi bića koja traže prostor slobode ili onakva kakvima ih tretira totalitarizam? ${ }^{56}$

Prirodno pravo svakog čovjeka izražava sklad sa svim vidovima njegove naravi: (raz)umnosti, intuitivnosti, duhovnosti, tjelesnosti, emocionalnosti. U analizama prirode i društva pri inzistiranju na ekvivalenciji prirodnog s religiozno

47 de Mattei, str. 59; Kulenović, 2003., str. 60.

48 Pera, str. 33

49 O historijatu samoodređenja. Usp. Marko Pranjić, „Paideia, starogrčka odgojno-obrazovna forma“", Metodički ogledi (16) 1-2, 2009., str. 13.

50 Usp. Häberle, 2006., str. 39.

51 Usp. de Mattei, str. 113; Šimić, str. 750.

52 Usp. Ratzinger, Bertone, str. 1/7.

53 Usp. Josip Grbac, „Pitanje univerzalne etike i univerzalne religije“, u: Kršćanka i/ili univerzalna etika, Josip Turčinović d.o.o. Pazin i Teologija u Rijeci, 2003., str. 57.

54 Koncep koristi Neven Sesardić u članku „Homoseksualni brak: pobjeda loših argumenata”, Prolegomena, 6 (1) 2007., str. 24-25.

55 Usp. Ivan Karlić, ,Identitet i dijalog u suvremenom europskom kontekstu. Doprinos kršćanstva suživotu u europskom kulturalnom i religijskom pluralizmu“, Filozofska istraživanja, 31 (2010.) 4 (o odricanju apsolutizacije vlastitom identitetu, kulturnom razoružavanju), str. 755-756.

56 Usp. Gordan Črpić, Damir Mravunac, Željko Tanjić, ,Supsidijarnost - širenje prostora slobode u društvu”, Bogoslovska smotra, Zagreb (79) 1, 2009., str. 92. 
transcendentnim iskaziv je nesklad u dokazivanju da je ljudsko (složeno, višeslojno) ujedno i nadnaravnog podrijetla. ${ }^{57}$ Može li se nespoznatljivo (tek vjerujuće) uzimati istinitim dok se takvim ne dokaže? ${ }^{58}$ Ta ekvivalencija aksioma i argumenata jedne doktrine s prirodnim moralom erozira toj doktrini neutralnost i objektivnost za pravilno vrednovanje, pa se njezina obveznost i opravdanje za legalizaciju (samo) prokazuje kao proizvoljna procjena (u vidu njezina zaključka) koja proskribira ine tradicije, savjesti jer zagovara violentni vanjski utjecaj na njih.

Ambivalentan stav religioznog o humanističko-laičkom okviru koji štiti (i vjerske) razlike među ljudima inicira drugačije državno tretiranje religije od inih tradicija. Svođenje savjesti na jednu, totalnu znači da ni različitost (savjest u potrazi) nije ispravna, pa je i njezina egzistencija proizvoljna. Takvim oduzimanjem etičnosti inim tradicijama religioznost kazuje da su one opravdano neravnopravne u poimanju općeg dobra. Moguća valjanost te konkluzije eksplicira da je i pravna jednakost tj. zakonska ravnopravnost ljudi izlišna. ${ }^{59}$ Dodatni paradoks jest što religija time negira i svoj izjavni stav o legalnosti pluralnog (pluralističkog) i (u civilnom sektoru) autonomnom desekularnom društvenom statusu čijoj poziciji u laičkoj državi i sama (načelno) teži. ${ }^{60}$

Religioznost sliku čovjeka ne izvodi iz njega (čovjeka), nego izvana; priroda je posljedica i ekvivalent teizmu. Humanističko-liberalna tradicija usmjerila je čovjeka na samoga sebe a da mu nije ograničila savjest u traženju nekog oblika transcendentnog. Dapače, laička ustavna kultura u pitanjima morala ne isključuje religiju. ${ }^{61} \mathrm{U}$ skladu složenosti naravi otvorila je prostor za minimalno tri izbora: transcendentizam, imanentizam i kompatibilni sinergijski oblik. Stvara li simbioza etike i religioznog veću nejasnoću zbog izražene monološke, autoritarno totalitarne komponente da vlastiti stav postane javna obveza jer ga izglasateljeva savjest smatra jedino moralnim? Ili je poroznija simbioza humanizma i etike, imanentnija svoj kompleksnosti, tj. trajnosti naravi u samosvojnoj potrazi? S obzirom na to da je ljudska narav uvijek ista (višeslojna), pluralni (pluralistički) okvir izražava elementarni minimum korektnosti svim tradicijama. Stoga religiozni građani u politici trebaju imati u vidu diskurs; vođeni isključivo vjerskim naukom za opće dobro svih ljudi, najavljuju ograničenje savjesti jednom dijelu građana jer će ih (taj) izglasani zakon obvezati. ${ }^{62}$ Inzistiranjem na tome religiozno se prokazuje borbenom ideologijom koja redukcijom prostora autonomije i potreba drugih, eskulpira

57 Neke vjerske zajednice tijekom zadnjeg stoljeća-dva mijenjale su dio svojih teoloških stavova utemeljenih na dogmi; npr. o evoluciji, drugim religijama i vjerskim zajednicama, znanosti, slobodi... upravo zbog napretka znanosti koji im je postao konkurentan.

58 Usp. Choen Morris, Nagel Ernest, „Uvod u logiku i naučni metod“, Zavod za izdavanje udžbenika SRS, Beograd, 1965., str. 218-240.

59 Usp. Pena-Ruiz, str. 115.

60 Usp. Matulić, str. 9.

61 Željko Mardešić, „Crkva, liberalizam, modernitet“, u: Liberalizam i katolicizam u Hrvatskoj-II., Freidrich-Naumann-Stiftung, Zagreb (usp. B. Latour), 1999., str. 458; Milan Lyčka, „Povratak religije/a u javnu sferu i uloga religije/a u današnjem društvu - češka perspektiva“, u: Religija i sekularna država, Međureligijski institut BiH, Sarajevo, 2007., str. 179.

62 Kulenović, ‘katolici će prihvatiti pluralizam ... ali kad se promijene okolnosti...', 2003., str. 60. 
sebe tražeći da drugima postane javna obveza. Zato joj je razumljiv oslonac na monološku esenciju u komunitarnoj teoriji kritike laičnosti i sekularizacije da potiču relativizaciju etičkih, (preciznije) vjerskih normi normativnim neskladom, inicirajući različita značenja valjanog, ispravnog, moralnog koji se koriste u definiciji etički relativnog. Ta je kritika 'per se' teorijski koherentna. No u realnom životu, upravo takva norma eksplicira da i dijelom etički različiti nikad i nigdje ne bi imali mogućnost aktivne koegzistencije. Laička pluraln(ističk)a realnost (na sreću) ukazuje na drugačiji zaključak. Kontra primjeri upravo su joj monološkokomunitarni koncepti i autoritarno-totalitarni režimi.

$\mathrm{Pa}$ ipak, i religiozni građani - motivirani teizmom, teže nadziranju vlastitog ukazujući na svoju moralnu ispravnost. Time su bliži inkluzivnim, laičkim zakonima jer oni štite slobodu savjesti. To znači suživot različih od civilizacijskog je značaja za njihov opstanak. Obveza države i jest da svojim autoritetom svakom subjektu društva (i najnižem subsidiariusu - svaki pojedini čovjek) omogući djelovanje po vlastitom identitetu. ${ }^{63}$ Stoga, da bi se izbjegla revitalizacija autoritarno-totalitarnih koncepcija, razumnije je (posebno o temi osobnog) ne koristiti privatne istine kao politički argument. ${ }^{64}$ Politička sfera zbog toga i ima autonomiju, svoju logiku i zakonitost drugačiju od religiozne. ${ }^{65}$ Ta je premisa etična jer osporava vanjski (državni, religiozni...) utjecaj na savjest ${ }^{66}{ }^{66}$ sto je u liberalnim pluraln(ističk)im demokracijama opravdano / samorazumljivo i prihvatljivo svim tradicijama. Da li onda legalni predstavnici trebaju izglasati religiozni zahtjev koji se dotiče osobnog? Ako je u skladu njihove savjesti, po ustavu mogu. Izglasan, i drugima postaje javna obveza nadređena njihovom osobnom (što savjest jest, i kad se sama mijenja uviđajući vlastite slabosti) i negira onaj dio laičke ustavne kulture koji štiti pravo izbora. Za koji su kao predstavnici naroda i izabrani da ga štite kao opće dobro. Time etatizacija religioznog ukazuje na dvostruku poroznost: negira 'pravilno razumijevanje digniteta ljudske osobe, zbog čega on ne smije biti izložen vanjskim utjecajima koji bi ograničili savjest $u$ traženju i prihvaćanju istinske religije ${ }^{67} \mathrm{i}$ humanistički argument o pravilnom tretiranju digniteta osobe jer ljudima inih tradicija ograničava savjest u traženju ${ }^{68}$

Evidentno, suživot različitih etičkih realiteta nudi laička legislativa. ${ }^{9}{ }^{9}$ Zašto je tako? Različitost kultura i etika splet je niza okolnosti kroz dugi razvoj čovjeka

63 Marijana Bađun, „Financiranje crkve u Hrvatskoj: trebaju li nam crkveni porezi?“, 2000., str. 6, http://zaklada-hanzekovic.ijf.hr/2000/badjun.htm, 8. siječnja 2009.; Hrvoje Špehar, „Europeizacija i eurolaicizacija: ključne prekretnice u odnosima Europske unije i crkava, religijskih zajednica i nekonfesionalnih organizacija”, Anali Hrvatskog politološkog društva, 6, 2009. (Lisabonski ugovor, čl. 17. Konsolidirane verzije Ugovora o funkcioniranju EU), str. 61.

64 Usp. Abazović, str. 195.

65 Nikola Bižaca, „O angažmanu katolika u politici“, Služba Božja, 50, 1, 2010., str. 97.

66 Usp. Ratzinger, Bertone, str. 3/7.

67 Ratzinger, Bertone, str. 3/7.

68 Arsen Bačić, „Ustav RH i najviše vrednote ustavnog poretka“, ZPFS, 49, 1/2012 (usp. C. R. Sunstein), str. 18; Bižaca str. 97-98.

69 Usp. Maritain, str. 162-164. 
tijekom njegove prošlosti. No, što im je (prvi) uzrok? Je li esencija (složenost / kompleksnost) ljudske naravi savjest u potrazi? Ako jest, je li etički pluralizam jedan od uvjeta za lišenost vanjskog utjecaja na savjest, ili je on baza za kulturni i etički relativizam? ${ }^{70}$ Religiozni lideri u potonjem vide uzrok normativnog nesklada i negaciju objektivnog morala koji se ozbiljuje samo u punoj religizaciji društva, za sve ljude. ${ }^{71}$ Ali i kao tlo gubitaka svoje vjerodostojnosti. ${ }^{72}$ No, ti mogući gubici primarno su posljedica etički upitnih odnosa države i religije, te poroznosti koji se javljaju u javnom djelovanju religioznih lidera. Ne (etičke / moralne) diferencijacije $\mathrm{u}$ društvu, ${ }^{73}$ jer društvo je sekularizirano ili desekularizirano upravo onoliko koliko građani, primarno na osobnoj razini - istinski žive vjernički, a na privatnoj - javnoj razini društva (imaju potrebu), življenje vjere prezentirati.

U javnoj raspravi kompeticije i etika jedne tradicije mogu se pokazati spoznajno boljim od drugih, biti informativan i formativan faktor. Iz konkurentnih tradicija može se iskristalizirati kompatibilni dio, ${ }^{74}$ kao sinergijski kriterij za pravilno tretiranje moralnog i pravednog (opće dobro). Ta supstanca ne bi smjela biti samo mehanički zbir partikularnih interesa. ${ }^{75}$ Upravo sinergijska konjunktura kriterija ukazuje na poroznost valjanosti i neutralnosti aksioma i argumenata koji neka tradicija pretpostavlja ako bi kao izglasan zakon bio vanjski utjecaj koji ograničava savjest u traženju. ${ }^{76}$ On bi negirao nadziranje vlastitog svojstvenog svakom čovjeku pa se pravednijim iskazuje da ljudi osobnost tretiraju autonomnim percipiranjem dobrog života kao minimum samointeresa, ${ }^{77}$ te da im drugi to pravo preko javnih institucija ne mogu uskratiti. Je li to i moralno, neovisno o ijednoj tradiciji? Ako nije, kako zaštititi ono što civilizacija (poučena lošim iskustvima) percipira dostojanstvom čiji je modus operandi njegova pravilnog razumijevanja upravo autonomna savjest?

I Drugi vatikanski koncil naglašava autonomije Crkve i Države, te poučava da $n i$ jedna vlast ne smije siliti čovjeka na (ne)pripadnost (i)religioznoj skupini / nauku, ${ }^{78}$ eksplicite savjesti. Traži li onda etatizacija religioznog ustavnu permisivnost u službi interesa njezine uprave i (dijela) članstva koja se lobistički (samo)projicira kao objektivni zaštitnik morala? Ako jest, kakvu bi poruku njenim prihvaćanjem

70 Usp. Pena-Ruiz, str. 63.

71 De Mattei, str. 109.

72 Alojzije Hoblaj, Gordan Črpić, ,Bitne vrednote u odgoju mladih naraštaja s posebnim osvrtom na školski vjeronauk“, Bogoslovska smotra (70) 2, 2000., str. 385.

73 Nenad Malović, „Laičnost - prilike i zablude”, usp. H. Joas, ukazuje na činjenicu da 'sekularizacija nije povezana s moralnom propašću društva' (2015., 435).

74 Usp. Šimić, str. 751-752; Bižaca, str. 99.

75 Bižaca (usp. Christifideles laici), str. 96-97. Sklad dijela orijentira religije i humanizma je očit. No težnje relogioznih lidera (latentnog političkog subjekta) k ostvarenju svojih interesa etatizacijom, druga su stvar.

76 Usp. Pena-Ruiz, str. 130-131.

77 Kulenović, 2009., str. 196-197; Mt., 7, 12.

78 Usp. Gaudium et spes, br. 36.;

http://www.zupa-svanastazija.com/images/dokumenti/Gaudium_et_Spes.pdf; Dignitatis humanae, 2, (1738.), http://www.katolici.org/katekizam.php?action=c_vidi\&id=1161, 5. siječnja 2010. 
o modelu odnosa i povjerenju u pravnu sigurnost odaslala vlast pluraln(ističk)om društvu?

\section{INSTITUT 'DEMOKRATSKE VEĆINE'}

'Vjera je javna jer je u službi vrednota. Zato nije privatna stvar.' ${ }^{9} 9$ To je čest argument za etatizaciju religioznog. Ta je tvrdnja dijelom razumna jer vjera $\mathrm{u}$ jednom specifičnom smislu znači opredjeljenje za istinu, jer za nju je sam bitak istina, razumljivost i smisao.$^{80} \mathrm{~K}$ tomu, religiozni čovjek kao društveno biće nije razdjeljiv na svjetovno ili sakralno, pa vjera ima i javnu funkciju. No, dogmatska neodredivost implicira i spekulaciju, te je vjera nužno osobna.$^{81} \mathrm{Te}$ su kvalifikacije esencija njezine egzistencije. ${ }^{82} \mathrm{~S}$ obzirom na njih, koju javnu razinu u pluralnom (pluralističkom) realitetu povlači njezina pravna pozicija? Privatnu, neobvezujuću javnost koja se osobnom voljom de/sekularizira? ${ }^{83}$ Ili državnu / lokalnu, koja eksplicite obvezuje građane i od sebe odvaja osobno? Po prirodi prezentacije osobnog, privatna javna (pravom izbora nelobvezujuća) razina i/religioznoj skupini eksplicite je nužna i štićena. Upravo je laičnost kao razvojni iskorak osigurala veću sigurnost i javnost neodredivom: različitim uvjerenjima, savjestima i njihovoj implementaciji u društvo i kulturu. ${ }^{84} \mathrm{Tu}$ je smanjen politički prostor pa je i/religioznost (pravno, sociološki, ontološki) usmjerena na civilni, neprisilan status. ${ }^{85}$

Dodatna je etička i pravna sumnja etatizacije religioznog u tome što građani, po laičkom ustavu, za isto ne mogu dati mandat. U suprotnom, institut demokratske većine $^{86}$ bio bi pravni instrument brojnije i/religiozne populacije u traženju implementacije i/religiozne ide(ologi)je u osobne živote manjine, a državu bi obavezao u provođenju unitarne svijesti, savjesti i emocije što povlači i kolektivnu odgovornost. Time većina stječe spoznajno i etičko pravo na odluku o moralno

79 Usp. Hoblaj, Črpić, str. 386.

80 Usp. Joseph Ratzinger, Uvod u kršćanstvo, Kršćanska sadašnjost, Zagreb, 2007., str. 146.

81 Markešić, 2005., str. 106; Hoblaj, Črpić, str. 359; Siniša, Zrinščak, „Što je religija i čemu religija: sociološki pristup", Bogoslovska smotra (78) 1, 2008., str. 29; Siniša Zrinščak, Gordan Črpić, Stjepan Kušar, „Vjerovanje i religioznost”, Bogoslovska smotra (70) 2 (usp. D. Hervieu-Leger), 2000., str. 248; Josip Baloban, Alojzije Hoblaj, Danijel Crnić, „Određeni aspekti crkvenosti u RH - rezultati i prosudbe istraživanja“, Bogoslovska smotra (80) 2, 2010., str. 535.

82 De Mattei, 'Kršćanstvo je nutarnja religija koja se ne može nametnuti silom', str. 111.

83 Zrinščak, 2005., str. 82; Zovkić (usp. U. King), str. 43.

84 Ahmet Alibašić, ,Modeli uređenja odnosa države i vjerskih zajednica u Evropi i SAD-u i njihove konsekvence“, u: Religija i sekularna država, Međureligijski institut BiH, Sarajevo, 2007., str. 96.

85 Bižaca, str 95; Peter Häberle, „Hrvatski ustav (1991.) u europskoj pravnoj usporedbi“, Politička misao (37) 1, 2000., str. 51-53. Položaj religije u RH dio je heterogenog trenda u Europi. No, naglasak na koordinaciju države i religije nije u skladu s Ustavom RH, jer narušava prava (slobodnog izbora) građana.

${ }^{86}$ U laičkim liberalnim pluralnim (pluralističkim) demokracijama ovaj institut je ustavnopravno legalan u samo dva slučaja: a) lokalni / parlamentarni izbori; b) referendumi o pitanjima koja ne narušavaju temeljna prava čovjeka. 
ispravnom za svakog čovjeka, a to tolerira tiraniju većine nad osobnošću pojedinca ${ }^{87}$ Negacijom realnih razlika, odozgo i izvana, stječe se upravljačka i materijalna moć nad svakim članom društva, a etički pluralizam - put humanijim odnosima među diferenciranom populacijom bio bi osporen unitarnim religioznim motivom i etički emotivizmom. ${ }^{88}$ Historiografija otkriva niz diskriminacijskih postupanja iz tih državno-pravnih pozicija. Svaki čovjek, odozdo i iznutra, može naći etičko suglasje $\mathrm{s}$ i/religioznima ${ }^{89}$ Premise te teze su: permisivnost prema osobnom životu drugih, $\mathrm{i}$ to što ta fleksibilsnost ne negira vlastitost, a konkluzija: evolucija korektnih odnosa $u$ svijest $i$ savjest društva. Taj osobni čin udovoljava minimumu samointeresa ljudima svih tradicija. Da ga se nije štitilo kroz civilnost, ne bi bila moguća ni zaštita digniteta i savjesti osobe od podržavljene monološke etike pa bi i odmetnuti članovi etatiziranog subjekta osjetili nesigurnost, što implicira širu destabilizaciju društva. ${ }^{90}$ To osvjetljava humani karakter laičnosti jer joj je u esenciji nazor koji u toj sferi uvažava u društvu sve prisutne duhovne opcije, a ne favorizira ni jednu. ${ }^{91}$ Stoga, represivno državno reguliranje i/religiozne obveze šteti i njoj samoj jer joj umanjuje pozitivni obol društvu, pa se mudrost političke vlasti ogleda u izbjegavaju kreiranja osobnih života građana. ${ }^{92}$ Društvo kontinuirano oblikuje procese pripadanja nekoj kulturi. Čovjek može razvijati i obogatiti svoj intelekt i smislenost spoznajući i druge vrednote, ${ }^{93}$ a njegov kvalitetan razvoj može biti neovisan o habitusu različitih društvenih skupina a da im istodobno dade pozitivan prinos. Jer, spoznajna i etička neovisnost $t^{94}$ impliciraju i detektiranje prednosti i slabosti na korist društva. Time kulturna sloboda uključuje i slobodu pojedinca kad on vidi razlog promjene načina života u namjeri da preispita svako automatsko podržavanje neke tradicije. Zato različitost ima pozitivnu ulogu u jačanju slobode, jer ako ona nije dopuštena, onda ni izbor (pa ni vjere) nije moguć. Stoga je nemoguće jednu sliku nametanu kao

87 Bobbio (usp. A. de Tocqueville), str. 67; Henry David Thoreau, „Građanska neposlušnost“, Diskrepancija (4) 7-8, 2003., str. 88/91.

${ }_{88}$ Argument Iustitia et pax HBK o ekvivalenciji instituta demokratska većina i vjerske statistike iz popisa stanovništva 2001. g.: „Postoji fakt da su statistički katolici većina, a socološki katolici manjina $u$ društvu, tj. da postoji intervenirajuća varijabla koja ureduje da to ne bude tako. Naime, ako je 80 \% katolika u društvu, onda bi 80 \% zastupnika trebalo biti katolicima, $80 \%$ na javnoj TV $i$ u javnim poduzećima, jer bi zastupljenost po zakonu velikih brojeva trebala biti takva. Ako nije takva, onda treba dokazati da postoji katolički gen koji je degeneričan što će teško dokazati ili je riječ o nečem drugom.", http://www.vecernji.ba/svijet/kaptol-katolici-su-u-hrvatskoj-diskriminirani-i-ugrozeni-304846, 26. kolovoza 2011. Suprotno tumačenje, v. Pena-Ruiz, str. 126-127, i Bačić, 2012., str. 20.

89 Usp. Grbac, 2003., str. 57.

90 Usp. Pena-Ruiz, str. 117.

91 Usp. Špehar, 'pluralna neutralnost', 2009., str. 61; Pena-Ruiz, str. 143; Željko Mardešić, „Kršćanstvo i sekularizacija“, Nova prisutnost (usp. R. Remond; o slobodi vjerskih skupina u laičkom društvu), 2006. (4) 2, str. 274-275.

92 Usp. Siniša Zrinščak, ,Religija i hrvatsko društvo“, Društvena istraživanja (3) 35, 1998., str. 349; Bobio, 1992., str. 25.

93 Elvio Baccarini, „Liberalizam, pojedinac, zajednica“, u: Liberalizam i katolicizam u Hrvatskoj, II., Freidrich-Naumann-Stiftung, Zagreb, 1999., str. 81.

94 Josip Baloban, „Vrednote u RH između deklarativnog i stvarno življenog“, Bogoslovska smotra, 77, 4, 'EU istraživanje 1999-2000.; naglasak na razvoju pojedinca', 2007., str. 797; Pena-Ruiz, str. 71. 
sveobuhvatan identitet doživjeti i kao svoju obvezu. ${ }^{95}$ Blagodati se mogu naći i u samostalnom postupanju i u užim kulturnim grupama ${ }^{96}$ unutar društva za čiju je stabilnost korisno da država omogući autonomiju smišljanja i provedbe života, ${ }^{97}$ pa se homogenizacija i solidarnost pojedinaca i skupina u bitnim (ponekad sudbonosnim) trenucima društva nameće kao holistički uzrokovana posljedica njegove pravno snošljive uređenosti. Subjekti zainteresirani za to i bez dokaza o 'ne/postojanju nadnaravnog tvorca' odnose mogu ugovarati humano i racionalno, sustavom vrednota koji štiti njihove razlike (i ne favorizira ih na štetu drugih)..$^{98}$ Zato i kvaliteta javne etike podliježe sinergijskom konceptu. Stoga i etatizacija religioznog implicira latentnu ideologizaciju i proskribiciju inog, ne slagao se on i samo s dijelom njezinih stavova. ${ }^{99}$

Spor pozicija: a) odozdo i iznutra-supsidijarno, ib) odozgo i izvana-etatizirano, osvjetljava moguću latentnu klerikalizaciju javnih zakona i implicirajuće etike. Tu se supsidijarnost i laičnost nadograđuju, a religioznost decentralizacijom čine civilnom (privatno javnom) i funkcionalnom. Utoliko laička ustavna kultura ima civilizacijski značaj jer ogoljava proizvoljnost i slabosti etatizacije privatnog / partikularnog ako isto nije u javnoj raspravi filtrirano i zbog iskristalizirane sinergijske kvalitete prihvaćeno. Time se kompleksnost naravi, dignitet osobe i sve prirodne i društvene razlike ljudi dovode u poziciju veće javne zaštite.

Europski laički okvir razumljiv je zbog objektivnih razlika građana koji generiraju interkulturalni i etički kontekst. Ali i zbog multikulturalnih okolnosti izgradnje identiteta tijekom duge prošlosti. ${ }^{100}$ Zato permisivnost domicilnih zakona prema religioznom da odozgo i izvana stekne ili zadrži privilegij ${ }^{101}$ implicira paradoks jer ta etatizacija inicira monokulturu i etiku, osnaženu statistikom. Deklariranje savjesti, uvjerenja ne znači da građanin (sve i da upravo to želi) može dati pravo državi (niti ona to smije uzurpirati) da upravlja (manipulira?) nad njim ili s tom statistikom nad drugima. To je razvojni dio humanističko-laičke ideje o pravednijoj državi. ${ }^{102}$ Da li onda ugovaratelj, potpisnik i donositelj ugovora involviranjem statistike ne/svjesno oтояис́ијu i manipulaciju vjerom i religijom? ${ }^{103}$ Naime, aspiracije

95 Ninčević, str. 61-62; Vujadinović (usp. D. Pantić), str. 30-31.

96 Usp. Elvio Baccarini, „Provedba morala putem zakona“, Politička misao (43) 3, 2006., str. 21/36.

97 Usp. Baccarini, 2006., str. 20/36; Karlić, str. 754.

98 Usp. Mardešić (o društvenim vrednotama i sporazumijevanju), 2006., str. 260.

99 Usp. Markešić, 2005., str. 107-108; Zrinščak, 2008., str. 29-30.

100 Kulturni korijeni i razvoj Europe su pluralni: antički, judeo-tro/kršćanski, 'barbarski', a od 8. st. islam je dao svoj obol. Usp. Vrcan, str. 11; Rodin, str. 8; Špehar (usp. W. Spohn), 2009., str. 61; Pera, str. 102; Karlić, str. 752.

101 Torfs, str. 33/38/40; Špehar (čl. 11. deklaracije Amsterdamskog ugovora 1999.), 2009., str. 60.

102 Usp. Pena-Ruiz, 113-117.

103 Državni zavod za statistiku, Popisnica za popis stanovništva RH 2001., pitanje br. 23, http:// www.dzs.hr/hrv/censuses/Census2001/popisnice/Template\%20P1.htm, i Popisnica za popis stanovništva RH 2011., pitanje br. 21, http://www.dzs.hr/Hrv/censuses/census2011/forms/P1-WEB.PDF, 5. travnja 2011. Izraz 'vjera' projekcija je duhovnog a idealnog i ljudima različitog (usp. Ćimić, 1992: 347.). Upiti sugeriraju da je dio građana bez ikakve vjere, duhovnosti, idealiteta ako nisu u skladu s oficijelnim mjerilima. Korektno bi bilo da u Popisnici piše opredijeljenost za vjersku zajednicu zbog onih koji vjeruju, 
vjerskih uprava idu za tim da država (financijski porezni obveznici, pravno i etički svi građani) zbog statistike tu privatnost honorira. Ustavna laičnost to niječe. ${ }^{104}$ Ta pravna dualnost inicira nejasnoće oko deletatizacije i intenzivira relevantnost manipulativne, suupravljački utilitarne egzegeze. Manjinskoj populaciji to može krnjiti ravnopravnost jer je u pravnoj državi koja stremi neutralnosti prema duhovnim opcijama, zbog slabe vidljivosti uvjerenja i osjećaja građana, liberalno-demokratski koncept krhak do samorazaranja. ${ }^{105}$ Nesumnjivo, i pluralnost nacionalnih državnopravnih okvira dio je europskog identiteta. ${ }^{106} \mathrm{No}$, homogenizacija nacije i domicilne religije ima(la je) dvojak karakter: a) društvenu koheziju, i b) diskriminaciju po političkoj, vjerskoj, etičkoj i etničkoj razlici. ${ }^{107}$ Stoga, kako se različita uvjerenja, savjesti mogu negirati, njihova deetatizacija generira dezideologizaciju legislative i veću javnu zaštitu svih tradicija. ${ }^{108}$

\section{KOMPATIBILNOST HUMANIZMA I RELIGIJE}

Ljudi religiju (dio tradicije koji može osvježiti, nadahnuti) neosporno doživljavaju smislenim izvorom, kao sigurnost i pomoć u izgradnji osobnog i profesionalnog života i društvene integracije. Traženje neodredive zaštite (idealiteta, vjere, oblika sreće) inicira olakšanje od negativne svakodnevice. ${ }^{109}$ No, neosporno je da religija nije nužna za kvalitetu života. Kler imanentno posl(anj)u traži vjersku praksu u životu religioznih kao teističku sliku o duhovnoj potrebi čovjeka. Taj odozdo i iznutra privatni javni dijalog ne iziskuje njezinu etatizaciju. ${ }^{110}$ Dapače, oslobađa izvorni vjerski doživljaj i slobodovoljnu asimilaciju (i/ino)religioznih građana kao članova ili simpatizera tog subjekta animatora, ${ }^{111}$ jer neprisilnost ('ribarenje $\left.d u \check{s} a^{\prime}\right)$ je kohezivna. ${ }^{112}$ Ona kroz civilnost štiti prednosti i slabosti (institucionalne

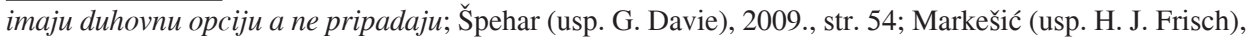
2005., str. 105. Ugovori... o gospodarskim pitanjima, čl. 6/6., o suradnji na području odgoja i kulture i o pravnim pitanjima - uvod. Spomenuti Ugovori pravno i etički nisu u skladu s laičkom normom Ustava RH koja osporava institut demokratske većine na osnovi religijske opredijeljenosti.

104 Komparacija čl. 3., 14., 16., 40., 41. i 140. Ustav RH.

105 Usp. Rodin, str. 7-8.

106 Häberle, 2000., str. 11.

107 Vujadinović (usp. N. Dimitrijević), str. 26; Miloš, str. 188-189.

108 Usp. Pena-Ruiz, str. 56.

109 Usp. Ankica Marinović Bobinac, „Posljedična dimenzija religioznosti“, Sociologija sela (38)

1/2, 2000., str. 122; Ivan Markešić, „Luhmannovo shvaćanje funkcije religije”, Društvena istraživanja, 3, 1998., str. 397.

110 Esad Ćimić, ,Religija i škola: Vjeronauka - pro et contra“, Nastava i vaspitanje, Beograd (41), 4-5, 1992., str. 347; Zrinščak, 2005., str. 82; Mt., 4, 19-20; Mk., 1, 17.; Lk., 5, 10-11.

111 Zoran primjer su Leah Libresco, http://hr.radiovaticana.va/storico/2012/07/31/bog_je_jedini_ uvjerljivi_odgovor!/cro-609461, 31. srpnja 2012. i Anthony Flew, https://www.bitno.net/vjera/vodecisvjetski-znanstvenik-ateist-tvrdi-bog-zaista-postoji/, 15. rujna 2012.

112 Usp. Bižaca, str. 102-103; Markešić, 2005., str. 106-107; Špehar (usp. M. Zetterbaum i B. Constant), 2011., str. 118-119. 
i) osobne i/religioznosti nesavršena (podožnog grijehu) čovjeka. ${ }^{113}$ Tako religija kao privatna javno prezentirana činjenica može u životnim dilemama opskrbiti idejama i identitetima, imati in/formativno-integrativnu ulogu, jer kako se mijenja čovjek, može mu se mijenjati i i/religioznost pa su različitosti, kompleksnost i složenost savjesti na djelu. ${ }^{114}$ I to u najdemokratskijoj maniri jer se osnovni principi ravnopravnosti i identiteta filtriraju kroz laičnost i de/sekulariziranu civilnost, tj. privatnu javnu sferu kao medijatore. ${ }^{115}$ Time i ne/prihvatljive ideje i/religioznog ovise (mjerljive su) i o kvaliteti njezinih argumenata i o njezinu javnom nastupu, ${ }^{116}$ u ime demosa na njegov res publicum. Upravo to ne isključuje religiju već je pozicionira kao neobvezujuću antropološku konstantu. ${ }^{1{ }^{17}}$ No, to humanističko-laički okvir ne čini agnostičko-ateističkim, već sinergijski kompatibilnim konstruktom za život različitih tradicija ${ }^{118}$ jer ne osporava življenje po vlastitom, koje se osobnom željom može javno prezentirati. Time i ljudska (trenutna, trajnija) anksioznost ima mogućnost izbora koji odozdo i iznutra može nadahnuti da se u nekom (i vjerskom) nađe želja i snaga za promjenu, novi početak. ${ }^{119}$ To snaži negiranje kritike po kojoj su laičnost i sekularizacija (negativno obojene) ide(ologi)je, etički i društveno nadmene religioznom ili inim duhovnim opcijama / idejama. ${ }^{120}$

Znanost je dokazala da je razvoj čovjeka stariji od nastanka (oficijelne) ${ }^{121}$ teističke slike i da se u različitim razdobljima i prostorima kvalitetno razvijao (i razvija) neovisno o njoj. Složenost današnjih etičkih načela posljedica je komparacije prošlih iskustava jer ih je kreirao i kultivirao čovjek koji je evoluirao. Time su i dijelovi religije, kompatibilni humanizmu, svojim skladom etatizirani. ${ }^{122}$ Zato bi ahistorijskim cementiranjem religiozne / dogmatske baštine u suvremenu javnu legislativu, a da bi se spriječili 'etički i kulturni relativizam' i laičnošću štićena i poticana pluralizacija (time i religizacija) privatne javne sfere, a unutar nje pozicije inih društvenih grupa, one bile ugrožene od privilegirane. Utoliko i sklad dijelova humanizma i religije ukazuje na logičku anomaliju argumenata koji idu za etatizacijom religioznog jer

113 Esad Ćimić, „Čemu predmet 'Kultura religija’?“, Revija slobodne misli, Asocijacija nezavisnih intelektualaca - Krug 99, Sarajevo (7) 31, 2001., str. 77; Ćimić, 1992., str. 347.

114 Usp. Zrinščak, 2005., str. 82; 2008., str. 30-31.

115 Abazović (usp. G. Vittamo i C. Taylor, u: T. Asad), str. 191.

116 Usp. Markešić, 2005., str. 107, Tanjić, ‘... polazište religijskih institucija nije više samorazumljivo. Ono se mora rekonstruirati ... na osobnom angažmanu svakog pripadnika religijske zajednice. Takav angažman jedino jamči univerzalan i objektivan pristup rješavanju dihotomija koje se u društvu naziru u postizanju društvenog konsenzusa', 2017., str. 663.

117 Abazović (usp. P. Berger), str. 189-190.

118 Usp. Lyčka, str. 179; Pena Ruiz, str. 13/21-25; Špehar, 2011., str. 124.

119 Usp. Pena Ruiz, 'laičnost i plemenitost', str. 105.

120 Usp. Mardešić (o sekularizaciji i čišćenju u religiji), 2006., str. 273-276/280.

121 Znanost, posebice arheologija, pronašla je više dokaza da (skoro) nikad nije postojala neka ljudska zajednica bez nekakvog oblika religioznosti, obreda, vjerovanja... u nad/naravno, koliko god on bio primitivan.

122 Etatizacija religije implicira određeni nesklad i s monoteizmom jer je slobodan izbor - volju čovjeku dao nadnaravni tvorac, sa svim konzekvencama. Usp. Knjiga Postanka, 3, 22/1; Sirah, 15, 14; Mladen Labus, „Društvene vrednote i religioznost“, Sociologija sela (43) 4, 2005., str. 841/850; Bačić, 2012., str. 6-7. 
ono eksplicira da savjesti treba vanjski utjecaj, što znači da čovjek nije slobodno i razumno biće koje bi moglo stvarati (stvoriti) pravedne i moralne norme.

Na svršetku nedovršenih procesa liberalizma i religije, jedni druge nisu nadmašili ni isključili. Za današnje je ljude moguće da u isti mah budu moderni i pobožni ${ }^{123}$ jer čovjek je duhovno biće, raz/uman je, slobodan i nesavršen, a to ne obvezuje niti narušava želju za agnostičkim, ateističkim ili teističkim vidom dobrog života. ${ }^{124} \mathrm{~Pa}$ iako između religije i modernizma postoje razlike, njihov sadržajni spor iniciran je vanjskim, monološkim aspiracijama religioznog na (inu) savjest. ${ }^{125}$ Očito je, načelno i stvarno, ljudima u pluralističkom (pluralnom) društvu mogu supostojati (pod)jednako valjane vrednote (koje osobnim izborom ne/obvezuju), a koje nisu u svemu u skladu. ${ }^{126}$ Može li onda javni zakon oslonjen na religioznost / dogmu biti kvalitetno rješenje realnih sporova?

\section{DEZIDEOLOGIZACIJA LAIČNOSTI I SEKULARIZACIJE, I KAO NORME I KAO PROCESA?}

Sociolozi dvojako definiraju suvremeni odnos države i religije; kao: laičku normu - politički stav o odvajanju vjerskih zajednica od javnih, državnih ovlasti i institucija s ciljem zaštite različitosti; i sekularni proces - koji razvojem neprisilne civilnosti uključuje kontroliranu desekularizaciju i/religioznih grupa. Kako odrediti granicu između tih oblika a da se izbjegne (negativno obojena) ideološka zamka?

$\mathrm{Ni}$ 'norma' ni 'proces' ne bi smjeli negirati obostranu pozitivnu nakanu. Nude li odgovor ustavni članci koji štite prava i obveze građana? Je li dezideologizirani odgovor u razvoju civilnosti? Ili se nazire u njihovoj sinergiji? U odnosu na 'proces', ustav snažnije naglašava 'normu' što religiji ne priječi puno aktiviranje. ${ }^{127}$ Dapače, no 'norma' se ne redefinira ako je supsidijarni 'proces' kontrolirano involviran, kao pomoćna privatna inicijativa. Preciznije, neškodljiv (poželjan?) čimbenik $u$ pojedinom slučaju. ${ }^{128}$ Utoliko 'norma' štiti svoju smislenost što građanima jamči

123 Usp. Mardešić, 1999., str. 458; 2006., str. 270.

124 Usp. Špehar, 2009., str. 279.

125 Usp. Josip Berdica, „Religija u misli Johna Rawlsa“, Obnovljeni život (63) 1, 2008., str. 31-32.

126 Usp. Gaudeamus et spes $(58,3)$; Mardešić, 2006., st. 262. Suprotno mišljenje vidi u zaključaku S. N. Bartulice (2016., 46).

127 Ustav RH, čl. 41. 1./2., 'odvojene od države ... uživaju zaštitu države' izražava pravno-politički karakter laičke države.

128 Isto, čl. 41./2., 'uživaju pomoć države'; Siniša Zrinščak, ,Religija, Crkva i treći sektor u Srednjoj i Istočnoj Europi“, Revija za socijalnu politiku (2) 4, 1995., str. 306; Zrinščak, 'opasnost norme ... granica javnog i privatnog rješava se kroz civilnost', 2005., str. 91; Reese-Schafer, str. 74. Pomoć države - u pojedinom (općekorisnom) slučaju ne bi smjela trajno srozavati ustavnu vrednotu odvojenosti, jer su u takvoj (trajnoj) situaciji 'odvojenost' i 'pomoć' jedno drugom ustavno-pravno suprotstavljeni., http:// www.protagora.hr/Iz-medija-clanak/O-ustavnom-okviru-i-modelu-duhovno-etickog-obrazovanja-udrzavnim-skolama-Republike-Hrvatske/468/. Sva tri ustavna atributa (odvojenost, zaštita, pomoć) podjednako su relevantna iako se 'odvojenost i pomoć' mogu smatrati i suprotstavljenima (u slučaju trajne, time i violentne, obveze građana). Zaštita je u demokratskom društvu samorazumljiva). No, odvojenost naglašava pravno-politički karakter države i privatni javno-društveni karakter vjerskih skupina, dok 
neprisilnost privatnog subjekta o čijoj su inicijativi u civilnosti stvoreni uvjeti slobodne kritičke rasprave koja generira ne/prihvatljive zaključke. ${ }^{129}$ Tako privatni subjekti animativnim argumentima mogu utjecati i na poboljšanje javnih zakona. No, civilnost je i medijator kvalitetnijem razotkrivanju predrasuda i latentnih partikularnih interesa ${ }^{130}$ koji se preko nje javljaju kao ozbiljne i trajne ideje. ${ }^{131}$ Stoga je religioznost prihvatljiva samo kao slobodni izbor koji tek (u pojedinom slučaju i) kontrolirano ulazi u državne / lokalne ovlasti. Time se i civilnost i 'proces' dezideologiziraju. To snaži prava građana jer takvo definiranje civilnosti priječi aspiracijama privatnih i/religioznih subjekata da postanu trajn(ij)a javna obveza. ${ }^{132}$ Istodobno se štiti ukupna društvenost prednosti i nedostataka i/religioznih grupa, a u javnom životu društva oba oblika; i 'norma', i 'proces' kroz civilnost, dezideologizirani sužive. Upravo relevantnost ustavne norme pravo izbora, koja esencijalno i po laičkoj ustavnoj kulturi inkorporira dostojanstvo $i$ ravnopravnost čovjeka, snažno egzistira kao modus operandi te dezideologizacije.

\section{UMJESTO ZAKLJUČKA: ODGOVORNOST DRŽAVE}

Iz realiteta apstraktnosti poruke, tj. dogme, i njezino je razumijevanje i tumačenje različito. ${ }^{133}$ To je, uz naslijeđene suupravljačke svjetovno-religiozne tradicije, uzrok

pomoć implicira (pravnu i financijsku) potporu privatnim vjerskim subjektima samo u pojedinim akcijama koje mogu implicirati realnu, opću korist društvu.

129 Reese-Schafer, str. 77; Vujadinović, str. 31-32.

130 Usp. Karlić ('platforma za dijalog ili neutralni teren', bilješka 24.), str. 761. Bruno Matos i Dalibor Renić u radu 'Postsekularizam: modeli interakcije religioznog i sekularnog poimanja racionalnosti' ističu koncept komunikativne racionalnosti Jürgena Habermasa koji podrazumijeva društvo u kojem se 'razmišljanja ravnopravno susreću i odmjeravaju, sukobljavaju ili podudaraju', jer: 'suvremenost traži dijalog vjere i razuma radi određenja prihvatljivog poimanja racionalnosti, te prijedlozima modela odnosa religije i sekularnog razuma koji bi tu potrebu dijaloga zadovoljili. ... Cilj je religiji omogućiti da svoju misiju nastavi u društvu tako da bude prihvaćena kao partner. Ne nekritički prihvaćena, nego upravo kritički, ali dijaloški.', 2016., str. 204./210./217.

131 Usp. Pažanin, str. 19.

132 Suprotna situacija je (npr. u RH) model javnog financiranja vjerskih zajednica i konfesionalni vjeronauk o kojima je kardinal Bozanić 13. listopada 2016. g. u intervjuu za HTV 1 kazao da su Ugovori Svete Stolice i RH za RKC u RH trajni, nepromjenjivi, http://vijesti.hrt.hr/356140/ekskluzivno-za-hrtbozanic-o-vjeronauku.

133 Laičnost - kao dio zapadne upravljačke kulture, zametke ima s kraja 5. st. u sakramentu ili dekretu pape Gelazija I. o dvije sile ili sablje (crkvenoj i državnoj vlasti), a imao je i, minimalno, dvije namjene:

a) da pape zadrže autoritet tumačenja prave dogme jer se kroz 3. - 5. st. širilo krivovjerje (maniheizam, pelagijanizam, arijanstvo, donatizam);

b) da pape izbjegnu podložnost kristijaniziranim barbarskim vladarima, kasnije i carevima. Teorijski korijen laičnosti svoju inicijaciju ima i u Evanđelju (v. Alibašić, 2007: 87); Mt., 22, 21., Iv., 18, 36. Dijalog u dvoglavom (Jacques Le Goff) srednjem vijeku zaključen je laičkom pa dvostrukom investiturom, onodobnim vidom laičnosti. Aspiracije klera za utilitarnim suupravljanjem uzrok su permisivnosti u odnosu na ortodoksni stav. Jačanje građanstva s težnjom umne, etičke i duhovne neovisnosti iznjedrilo je humanizam i prosvjetiteljstvo. Suvremenost Gelazijeva dekreta ogleda se i u izjavi pape Ivana Pavla II. povodom 100. obljetnice Zakona o laičnosti u Francuskoj iz 1905. g.: 'U odvajanju vlasti između građanskih i političkih, te crkvenih ustanova, odražava se Kristov nauk o davanju Bogu onoga što je Božje, a caru carevo.' (vidi, S. Dalmacija, 14. veljače 2005., http://arhiv.slobodnadalmacija.hr/20050214/ 
Damir Bulat: Spor etika - građanska prava i pravni položaj vjerskih zajednica u pluraln(ističk)om... Zbornik radova Pravnog fakulteta u Splitu, god. 55, 3/2018., str. 639.- 665.

različitih pravnih modela odnosa. $\mathrm{K}$ tomu, vrijeme u kojem živimo inicira da državne vlasti ponekad osjećaju strah od vjerskih zajednica. ${ }^{134}$ Delaicizacija osnažena javnopravnom osobnošću religioznog nad državnim ovlastima ${ }^{135}$ eksplicira i državni oktroj nad građanima jer im vlast ugovorom s religioznim kolektivno narušava dio prava koja im jamči ustavom. To znači da pluraln(ističk)om društvu javna obveza nije ustav, ${ }^{136}$ već ugovoreni sadržaj države i vjerskih skupina. Njihov pravni i etički nesklad otvara dva fluktuirajuća pitanja: 137

a) Je li ustavna država laička, a civilno društvo sekularizirano ili desekularizirano?

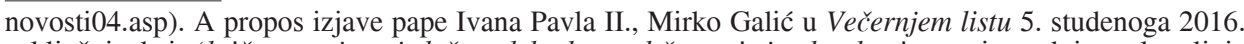
zaključuje da je "laičnost najmanje loš model odnosa državne i vjerske vlasti, a svoju tvrdnju potkrepljuje citatom katoličkog lista La Croix iz 2005. g. povodom 100. obljetnice Zakona o laičnosti u Francuskoj: 'da mu ne treba ništa ni dodavati ni oduzimati', usp. Pena-Ruiz, str. 93.

134 Torfs, str. 40.

135 Uzelac, ' $u$ sustavu javne pravne osobnosti svećenici vrše neke funkcije države', str. 278-281/517.

136 Arsen Bačić, ,Sudac i ustavna demokracija: Dr. sc. Jadranko Crnić, čuvar Ustava“, Zbornik PFS, (46) 2, 2009. (Ustavni sud RH je veto-igrač), str. 282; Ustav RH, čl. 3. O pravnom okviru u RH: Ustav RH čl. 140. ističe da međunarodni ugovori trebaju biti $u$ skladu s Ustavom RH. No, jesu li Ugovori Svete Stolice i RH u potpunosti usklađeni s Ustavom RH kad čl. 41./1. izričito navodi odvojenost vjerskih zajednica od države. Vape li ti Ugovori (sklopljeni u zgodnom političkom trenutku) za ozbiljnom pravnom revizijom? Da paradoks bude veći, Ustavni sud RH (a trebao bi biti veto igrač (građanima); vidi Bačić (2009., 282) donio je odluku u rješenju br. U-I-825/2001. (v. NN, br. 16/04.) da nije nadležan za odlučivanje o ustavnosti međunarodnih ugovora po (tadašnjem) čl. 128. Ustava. Drugim riječima, izglasavanje 2/3 većinom Ugovora Svete Stolice i RH od zastupnika Sabora RH 1998. g., iako neusklađeno Ustavu RH čl. 41/1., zaobilaznim, tj. međunarodnim putem obvezalo je (pravno, financijski, što dugoročno projicira i etičku opravdanost) sve građane RH. Koji je od ta dva pravna akta (Ustav RH s jedne, i međunarodni Ugovori Svete Stolice i RH ili ini unutardržavni ugovori s ostalim vjerskim zajednicama s druge strane) pravno valjan, tj. građanima obvezan, kad su jedan drugome dijelom neusklađeni, čak dijelom proturječni? K tomu, i Zakon o pravnom položaju vjerskih zajednica u RH treba biti u skladu s Ustavom RH po čl. 5., ne s međunarodnim ugovorima. Suprotno mišljenje o pravnom okviru u RH daje Šalković (2011., 121-130). Ono se nazire u tezi da religijske institucije teže za tim da njihov legitimitet bude utemeljen iznad i izvan povijesti, pa stoga nije podložan promjenama i kritici. O konfesionalnosti kao trajnoj, nepromjenjivoj značajki za pojedinca, vidi Boneta (2007., 414/415). Ako je pravni okvir Ustava $\mathrm{RH}$ iz čl. 41/1. pravno manje relevantan prema ovoj situaciji, onda tvrdnja o 'zabetoniranosti' pravnog položaja RKC-a u RH (vidi Staničić, 2014., 242), a ustavne ravnopravnosti i inih konfesija, čini mogućnost revizije tih Ugovora pravno izlišnom, jer RKC i ostale vjerske zajednice teško da će (ikad) samovoljno pristati na manje povoljnu pravnu poziciju. No, o pravnom okviru o međunarodnim Ugovorima između Svete Stolice i RH o suradnji na području odgoja i kulture sudac Ustavnog suda RH Andrej Abramović ima drugačije / izdvojeno mišljenje (br. U-I-2234/2017): ‘...međunarodni ugovori, prema svojoj pravnoj snazi, nalaze ... iznad zakona, ali svakako ispod Ustava. Iz tog slijedi da i oni, kao i svi ostali zakoni i propisi nižeg ranga, moraju biti usklađeni s Ustavom. U konkretnom slučaju prijedlog za ocjenu ustavnosti trebalo je meritorno riješiti.' Sudac Abramović, očito (za razliku od svojih kolega), smatra da je Ustavni sud RH ovlašten i da mu je zadaća provoditi ustavnosudsku kontrolu međunarodnih ugovora kako bi se spriječila implementacija eventualno neustavnih odredaba u pravni sustav RH, http:// www.index.hr/vijesti/clanak/ustavni-sud-nema-nista-protiv-vatikanskih-ugovora-ali-jedan-ustavnisudac-nasao-im-je-veliku-zamjerku-/978568.aspx. Je li mišljenje suca A. Abramovića na tragu mišljenja suca J. Brandiessa o 'Ustavu (koji) se bavi suštinom, a ne sjenama' (vidi Bačić, 2012., 18), time i o Ustavnom sudu kao 'veto-igraču', pitanje je za ustavno-pravne stručnjake.

137 'Ustav je svetinja ... ima služiti kao svjetovna Biblija lijepe naše Domovine', simplificirano i simbolički, očito ponukan različitim tumačenjima o nizu javno raspravljanih tema, u više navrata kazao je bivši predsjednik Ustavnog suda RH, prof. dr. sc. Jadranko Crnić, http://www.uhs.hr/data_sve/index_ text_povelja.htm ('čuvar ustava', okarakterizirana je njegova osoba i funkcija; vidi Bačić, 2009., 272), s nastojanjem razjašnjenja (za dio javnosti očito) pitijske pozicije Ustava $\mathrm{RH}$. 
Damir Bulat: Spor etika - građanska prava i pravni položaj vjerskih zajednica u pluraln(ističk)om... Zbornik radova Pravnog fakulteta u Splitu, god. 55, 3/2018., str. 639.- 665.

b) Je li liberalna pluraln(ističk)a demokratska država klerikalizirana ako je ugovor državnog i religioznog pravno nadređen $i$ (dijelom) neusklađen / suprotan ustavu?

Svjesno štićena pluralizacija društva i civilizacijski iskorak ukazuju da se točke ' $a$ i $b$ ' međusobno isključuju jer točka $b$ narušava temelje ustavne demokracije: proceduru - odvajanje od državnih institucija i ingerencija; i sadržaj - pravo izbora ne/apstiniranja od bilo kakvog oblika ine privatnosti. Ugrožava li laička norma vjerska prava građana ili osporava političke, historijski motivirane, aspiracije uprava vjerskih zajednica? ${ }^{138}$ Od zakonodavnog tijela izglasane neusklađene obveze (ustav ${ }^{139}$ i ugovor / države i vjerskih skupina) progresivno snaže tezu o mogućem narušavanju prava čovjeka etatizacijom religioznog. Utilitarizam državnih i vjerskih suupravljača izražava obostranu podršku pravdanu homogenizacijom po kojoj religioznost, postavši (partikularna) ekskluziva unutar državne strukture, narušava ustavni laički okvir. ${ }^{140}$ To ugovorom inicira i generira sama država. Je li to inverzivno i težnji vjerskih zajednica da supsidijarno kroz civilni sektor pomažu društvu i daju obol depaternalizaciji države? ${ }^{141}$ Ako jest, u neskladu je i sa sekularnim procesom. U interesu je države, građana i vjerskih zajednica nemiješanje uloga i zaštita privatne javne od državne javne razine, jer relativiziranje i raslojavanje ustavnih prava čovjeka permisira vanjskom utjecaju na savjest, a to potkopava dio laičke liberalne demokratske pluraln(ističk)e kulture. ${ }^{142}$ I međunarodni orijentiri obvezuju državu u zaštiti prava izbora od privatnih subjekata. To znači da država pri dogovoru tih

138 Nimac, Ćurković Nimac, 'liberalizam nije protiv religije, već vjerskih zajednica koje su tijekom prošlosti imale utjecaj na razvoj društva $i$ bile u koaliciji s raznim apsolutizmima $i$ totalitarizmima. (2014., 129).

139 Ustav RH, čl. 3., 5., 41., 80., 138., 139. i 140. U Saboru RH izglasani Ugovori Svete Stolice i RH ukazuju na pravni neskald po čl. 140. jer eksplicitni čl. 41./1. Ustava ostaje na snazi. Mogu li sporni dijelovi međunarodnog ugovora biti dio pravnog poretka RH ako nisu u skladu s Ustavom RH? Naime, je li u skladu s Ustavom RH da Sabor RH odobri nešto što nije u skladu s vrednotom Ustava o zaštiti ljudskih prava i temeljnih sloboda, tj. odvojenosti - na kojoj se (po Ustavu) temelji dio pravne uređenosti Države, i odnosi između svjetonazorski različitog političkog naroda?, vidi http://www.protagora.hr/Iz-medijaclanak/O-ustavnom-okviru-i-modelu-duhovno-etickog-obrazovanja-u-drzavnim-skolama-RepublikeHrvatske/468/.

140 Usp. Dinka Marinović Jerolimov, „Društvene i religijske promjene u Hrvatskoj: teorijskohipotetski okvir istraživanja“, Sociologija sela (43) 2, 2005., str. 290; Abazović (o religiji i politici u tranzicijskim zemljama), 2007., str. 193; Ankica Marinović-Bobinac, Goran Goldberger, ,Glas Koncila - poslanje ili tek ime: analiza komentara u razdoblju društvene tranzicije“, Sociologija i prostor (45) 3-4, 2007., str. 294. Homogenizacija različitih subjekata u specifičnim periodima korisna je društvu. Svjesno produljivanje inicira manipulaciju jer miješa ovlasti aktera. Za razvoj društva to povlači konfliktne kontraefekte jer akterima ni relevantne ovlasti ni dionice nisu iste (vidi Mardešić, usp. R. Remond, 2006., 274-275).

141 Usp. II. vatikanski koncil, dokument 1885.: 'Načelo supsidijarnosti protivi se svim oblicima

kolektivizma', http://www.katolici.org/katekizam.php?action=c_vidi\&id=1265, 5. siječnja 2010.

142 U radu „Podijeljenosti u hrvatskom društvu: mogući uzroci i posljedice u perspektivi Ivana Rogića i Željka Mardešića“, Željko Tanjić piše: 'Zajednica uvijek ima nutarnji poriv za opstankom, dok je društvo po svojoj naravi disperzivno', 2017., str. 663. Upravo aspiracije vjerskih zajednica za penetracijom u državnu javnu (svim građanima pravno, financijski, a dugoročno i etički obvezujuću) sferu, nastoje liberalno pluraln(ističk)o demokratsko društvo (i državu) učiniti zajednicom. 
sadržaja treba voditi brigu o civilizacijskom dosegu i razvoju društva,,${ }^{143}$ jer pravo i pravednost i u glavnim sferama nisu samo na raspolaganju, vladavina naroda. Oni su narodu kao kultura i zadani, vladavina prava, tj. ne proizlazi sve pravo iz naroda, ali ga valja misliti s aspekta dostojanstva svakog čovjeka. ${ }^{144}$

Poslovičnom gipkošću i moćnom refleksivnošću spram nadmoći i ne malim učinkom u ublažavanju socijalnih napetosti religija je uspješno konkurirala drugim duhovnim silama. ${ }^{145}$ Distanciranjem od politike često je stjecala neslućeni moralni prestiž, a suudruživanjem s njom najviše je mogla biti trenutno učinkovita. ${ }^{146}$ Počest oslonac na poslovičnu gipkost ukazuje na to da javnu ulogu religioznog njegova uprava tretira smislenim tek kad je podržavljeno, tj. kad su im zbog statistike i nacionalnog karaktera dane specifične prednosti. ${ }^{147}$ Tada je građanima obvezna pozicija i uloga njezine uprave koja svoju egzegezu i egzistenciju, odozgo i izvana (kroz javnu legislativu), inkorporira u društvo (posljedično i u privatnost građana). Neovisno i o volji dijela religioznih koji uviđaju da takva etatizacija srozava vjerodostojnost religioznog. To generira diferencijaciju i dehomogenizaciju religioznog puka vidljivu kroz različitost motiva deklariranja što uz suživot visoke statistike i niske vjerske prakse, odozdo i iznutra, prokazuje poroznost njezina dekoruma. ${ }^{148}$

Iako su vjerske vrednote suštinski monološkog karaktera, one potiču i zaštitu niza prava čovjeka, a po tomu su kompatibilne humanizmu, liberalizmu i laičnosti koji zainteresiranom religioznom puku ne osporavaju njihovu kvalitetu i (samo)

143 Konvencija EU-a o ljudskim pravima ..., čl. 9. i 14., http://www.mhrr.gov.ba/PDF/ UredPDF/?id=310, 2. svibnja 2009.; Deklaracija UN-a o pravima čovjeka, čl. 2., 7. i 12.; Ugovor ... o pravnim pitanjima, uvod - 'pozivajući se na međunarodno priznata načela o slobodi vjere i savjesti' .

144 Usp. Häberle, 2006., str. 9/15/25/33/38-39. Jure Perišić u radu „Balkansko u dinarskome mentalitetu: teološko viđenje dinarskog utjecaja na konstituiranje suvremene hrvatske države“, Obnovljeni život, 2016. (71) 1, odlično primjećuje da je 'demokratski sustav utemeljen na shvaćanju u kojem demos subzistira u narodu, a narod u svakom pojedincu; iz pojedinca onda proizlazi i sam politički legitimitet', str. 110.

145 Ćimić, 1992., str. 349.

146 Ćimić, 2001., str. 80-81.

147 Usp. Ankica Marinović-Bobinac, „Analiza sadržaja stavova Katoličke crkve u RH prema tranzicijskim procesima“, u: Liberalizam i katolicizam u RH, II., Friedrich-Naumann-Stiftung, Zagreb, 1999., str. 387; Marinović-Bobinac, Goldberger, str. 295; Markešić, 2005., str. 106; Torfs, str. 37; Perišić, 2016., str. 111/113-114.

148 Alojzije Hoblaj, Nevenka Lončarić-Jelačić, Ružica Razum, „Crkva i odgoj u Hrvatskoj“, Bogoslovska smotra (75) 1, 2005. (o diferencijaciji religiozno deklariranih), str. 294; Baloban (period 1997.-2007., o padu povjerenja u konfesije u percepciji građana RH), 2009., str. 750; Gordan Črpić, Siniša Zrinščak, „Dinamičnost u stabilnosti: Religioznost u Hrvatskoj 1999.-2008., Društvena istraživanja (19) 1-2, 2010. (o porastu broja ireligioznih građana u RH), str. 8/17-18; Baloban, Hoblaj, Crnić, str. 554-555; Špehar (usp. D. Hervieu-Leger), 2009., str. 54; Hrvoje Špehar, „Historijski razvoj odnosa Crkve i Države u V. Britaniji: ključne prekretnice i metamorfoze 'državne crkve' u multikulturalnom društvu“, Anali hrvatskog politološkog društva (usp. P. Norris, R. Inglehart, P. Berger), 7 (1) 2010., str. 189. 
ostvarenje. ${ }^{149}$ Dapače, takav okvir stvara (pred)uvjete za suradnju različitih. ${ }^{150}$ Tako religiozno može, i u vlastitoj egzegezi i u humanističkom poimanju duhovnog i etičkog, sebe ostvariti sadržajnijim i slobodnijim subjektom društva. ${ }^{151}$ I oštrica opravdanih prigovora njezinoj upravi i nizu iniciranih akcija otupjela bi ako bi se u skladu slova i duha laičkog ustavnog okvira preciznije (re)definirala njezina pravna, javno obvezujuća (državna / lokalna) pozicija. ${ }^{152}$

\section{LITERATURA:}

Abazović, Dino, „Sekularizam i sekularizacija u sadašnjem javnom diskursu - iz ne religijske perspektive“, Zbornik radova: Religija i sekularna država,

Međureligijski institut u BiH, Sarajevo, 2007., str. 189-195.

Alibašić, Ahmet, „Modeli uređenja odnosa između države i vjerskih zajednica u

Evropi i SAD-u i njihove konsekvence“, Zbornik radova: Religija i sekularna

država, Međureligijski institut u BiH, Sarajevo, 2007., str. 83-104.

Choen, Morris - Nagel, Ernest, Uvod u logiku i naučni metod, Zavod za izdavanje udžbenika SRS, Beograd, 1965.

Baccarini, Elvio, „Liberalizam, pojedinac, zajednica“, Liberalizam $i$ katolicizam u Hrvatskoj - II. dio, Friedrich - Naumann - Stiftung, 1999., str. 71-89.

Baccarini, Elvio, „Provedba morala putem zakona“, Politička misao, 43, 2006., 3, str. 19-38.

Bačić, Arsen, „Sudac i ustavna demokracija: Dr. sc. Jadranko Crnić kao čuvar Ustava“, Zbornik PFS, 46, 2/2009., str. 271-286.

Bačić, Arsen, „Ustav RH i najviše vrednote ustavnog poretka“, Zbornik PFS, 49, 1/2012., str. 1-21.

Bađun, Marijana, Financiranje crkve u Hrvatskoj: trebaju li nam crkveni porezi? http://zaklada-hanzekovic.ijf.hr/2000/badjun.htm, 28. siječnja 2009.

Baloban, Josip, „Vrednote u Hrvatskoj između deklarativnog i stvarno življenog“, Bogoslovska smotra, 77, 2007., 4, str. 793-805.

149 U radu „Teološki pogled na vrednote u hrvatskom društvu“ Špiro Marasović zaključuje: ‘... na ljestvici vrednota u prvi plan izbijaju individualne i opće humane; promatrane po sebi one kršćanstvu nisu inkompatibilne, naprotiv ...', 2001., str. 329.

150 Usp. Papa Benedikt XVI, Caritas in veritate, Kršćanska sadašnjost, Zagreb, 2010. (o suradnji različitih), str. 95-96; Ivan Pađen, „Katolicizam i nacionalizam u Hrvata 1990-ih: pravnoteorijski pogled II“", u: Liberalizam i katolicizam u Hrvatskoj, II, Friedrich-Naumann-Stiftung, Zagreb, 1999. (o sekularizaciji), str. 240.

151 Usp. Mardešić, 'o slobodi vjerskih zjednica u sekulariziranom društvu', 2006., str. 274.

152 Ustav RH, čl. 140., Ugovori ... o gospodarskim (čl. 15/2.) i pravnim pitanjima (čl. 19/2.) i odnosima na području odgoja i kulture (čll. 15/2.); Špehar (usp. D. McClean), eurolaičnost - jedinstvena javna sfera koja se ne smije privatizirati), 2010., str. 180/183. 
Baloban, Josip, „Pozicija i uloga Crkve u Srednjoj i Istočnoj Europi 20 godina nakon urušavanja komunističkog sustava“, Bogoslovska smotra, 79, 2009., 4, 739-753.

Baloban, Josip - Hoblaj, Alojzije - Crnić, Danijel, ,Određeni aspekti crkvenosti u RH rezultati i prosudbe istraživanja“", Bogoslovska smotra (80) 2, 2010., str. 527- 561.

Bartulica, Stephen Nikola, „Liberalizam i religija“, Nova prisutnost, 14 (2016.) 1, str. 33-47.

Berdica, Josip, „Religija u misli Johna Rawlsa“, Obnovljeni život (63) 1 (2008.), str. 21- 33 .

Biblija, Kršćanska sadašnjost, Zagreb, 1991. 103.

Bižaca, Nikola, „O angažmanu katolika u politici“, Služba Božja, 50, 2010., 1, str. 91-

Bobbio, Norberto, Liberalizam i demokracija, Zagreb, 1992.

Bognar, Branko, „Stvaralački pristup znanosti“, Metodički ogledi, 15 (2008.), 1, str. 11-30.

Boneta, Željko, 2007., „Konfesionalnost i (dez)integracija višeetničkih područja“,

Migracijske i etničke teme 23 (4), str. 409-422.

Črpić, Gordan - Zrinščak, Siniša, „Dinamičnost u stabilnosti: Religioznost u Hrvatskoj1999. i 2008. g. “, Društvena istraživanja, 19, 1-2 (105-106), 2010., str. 3-27.

Črpić, Gordan - Mravunac, Damir - Tanjić, Željko, ,Supsidijarnost - širenje prostora slobode u društvu“, Bogoslovska smotra, 79, 2009., 1, str. 91-111.

Ćimić, Esad, „Religija i škola: Vjeronauka - pro et contra“, Nastava i vaspitanje,

Beograd, 1992., 41, 4 - 5, str. 345-354.

Ćimić, Esad, „Čemu predmet 'Kultura religija'?“, Revija slobodne misli, Asocijacija nezavisnih intelektualaca - Krug 99, 7, 31., 2001., Sarajevo, str. 77-85.

De Mattei, Roberto, Diktatura relativizma, Verbum, 2010.

Đorđević, Jovan, „Moralno vaspitanje, religijsko vaspitanje i škola“, Nastava $i$ vaspitanje, Beograd, 1992., 41, 4 - 5, str. 327-344.

Grbac, Josip, „Pitanje univerzalne etike i univerzalne religije“, Zbornik radova:

Kršćanska i/ili univerzalna etika, Josip Turčinović d.o.o., Pazin i Teologija u Rijeci, 2003., str. 51-73.

Grbac, Josip, „Političko-društveni vid supsidijarnosti: Teoretsko utemeljenje supsidijarnosti u društvenom i političkom životu“, Bogoslovska smotra 79, 2009., 1, str. 11-61.

Grubišić, Ivan, „Vjeronauk u odgojno-obrazovnom procesu - da ili ne?“, Crkva u svijetu, 26 (1), 1991., str. 74-79.

Häberle, Peter, „Hrvatski ustav (1991.) u europskoj pravnoj usporedbi“, Politička misao, 37 (2000.) 1, str. 49-55. 
Häberle, Peter, „Ustav kao kultura“, Politička misao, 37 (2000.) 3, str. 3-21.

Häberle, Peter, ,Ljudsko dostojanstvo i pluralistička demokracija“, Politička misao, 43 (2006.), 2, str. 3-41.

Hoblaj, Alojzije - Črpić, Gordan, „Bitne vrednote u odgoju mladih naraštaja s

posebnim osvrtom na školski vjeronauk“, Bogoslovska smotra 70 (2000.), 2., str. 359393.

Hoblaj, Alojzije - Lončarić-Jelačić, Nevenka - Razum, Ružica, „Crkva i odgoj u

Hrvatskoj, Istraživanje za europsku komparativnu studiju“, Bogoslovska smotra, 75, 2005., 1, str. 289-313.

Jozić, Tomislav, „Hrvatske tradicijske vrednote i budućnost“, Zbornik radova:

Kršćanska i/ili univerzalna etika, Josip Turčinović d.o.o., Pazin i Teologija u Rijeci, 2003., str. 73-89.

Karlić, Ivan, „Identitet i dijalog u suvremenom europskom kontekstu. Doprinos

kršćanstva suživotu u europskom kulturalnom i religijskom pluralizmu“, Filozofska istraživanja, 31 (2011.), 4, str. 751-764.

Kulenović, Enes, „Ratzinger protiv Rawlsa: propast preklapajućega konsenzusa“,

Politička misao, 40, 2003., 1, str. 55-61.

Kulenović, Enes, „Pluralistička teorija utemeljenja ljudskih prava“, Politička misao, 46, 1, 2009., str. 193-198.

Labus, Mladen, „Društvene vrednote i religioznost“, Sociologija sela, 43, 2005., 4 (170), str. 837-853.

Lyčka, Milan, „Povratak religije(a) u javnu sferu - uloga religije(a) u današnjem društvu - češka perspektiva“, Zbornik radova: Religija i sekularna država, Međureligijski institut u BiH, Sarajevo, 2007., 179-185.

Lopez, Alonso Carmen, „Laičnost ili odvajanje države od religije u zapadnoeuropskoj tradiciji“, Zbornik radova: Religija i sekularna država, Međureligijski institut u $\mathrm{BiH}$, Sarajevo, 2007. g., str. 49-59.

Malović, Nenad, 2015., „Laičnost - prilike i zablude”, u: Zbornik radova XX.

međunarodnog teološkog simpozija Laička država-Religija-Crkva: od ideologizirane neutralnosti do prostora dijaloškog suživota, Crkva u svijetu, 50, 3, str. 427-444.

Marasović, Špiro, „,Teološki pogled na vrednote u hrvatskom društvu“, Bogoslovska smotra (71), 2-3, 2001., str. 319-340.

Marinović Bobinac, Ankica, ,Analiza sadržaja stavova Katoličke crkve u RH prema tranzicijskim procesima“, Liberalizam i katolicizam u Hrvatskoj - II., Friedrich Naumann - Stiftung, 1999., str. 373-387.

Marinović Bobinac, Ankica, „Posljedična dimenzija religioznosti“, Sociologija sela, Zagreb, 38 (2000.), 1/2 (147/148), str. 111-124. 
Marinović Bobinac, Ankica - Goldberger, Goran, „Glas Koncila - poslanje ili tek ime: analiza komentara u razdoblju društvene tranzicije“, Sociologija i prostor, 45 (2007.), 177 - $178(3-4)$, str. 269-299.

Marinović Jerolimov, Dinka, „Društvene i religijske promjene u Hrvatskoj: teorijskohipotetski okvir istraživanja“, Sociologija sela, 43 (2005.), 168 (2), str. 289-302.

Maritain, Jacques, Čovjek $i$ država, Globus - Školska knjiga, Zagreb, 1992.

Mardešić, Željko, „Crkva, liberalizam, modernitet“, Liberalizam i katolicizam u Hrvatskoj - II., Freidrich - Naumann - Stiftung, Zagreb, 1999., str. 447-459.

Mardešić, Željko, „Kršćanstvo i sekularizacija“, Nova prisutnost, 2006. (4) 2, str. 256280.

Markešić, Ivan, „Luhmannovo shvaćanje funkcije religije“, Društvena istraživanja, 3, 1998., str. 375-379.

Markešić, Ivan, „Religijska situacija u postmodernom vremenu“, Društvena istraživanja (14) 75 - 76 (1-2), 2005., str. 97-112.

Matos, Bruno - Renić, Dalibor, „Postsekularizam: modeli interakcije religioznog i sekularnog poimanja racionalnosti“, Nova prisutnost 14 (2016.), 2, str. 203-218.

Matulić, Tonči, „Jednakost i nediskriminacija: Vrijednosna polazišta u suzbijanju Diskriminacije“, Zbornik PFZ, 59 (1), 2009., str. 7-31.

Miloš, Matija, „Sloboda isticanja vjerskih simbola u svjetlu odvojenosti vjerskih organizacija od države“, Zbornik PFZ, 61, 1 (2011.), str. 181-196.

Ninčević, Marino, „Interkulturalizam u odgoju i obrazovanju“, Nova prisutnost (7) 1, 2009., str. 59-83.

Nimac, Dragan - Ćurković Nimac, Jasna, „Religija kao socijalni kapital u kontekstu sigurnosne politike suvremenoga europskog društva“, Bogoslovska smotra, 84 (1), 2014., str. 111-136.

Offe, Claus, „Tocqueville, Weber i Adorno u Americi. Hoće li se Europa amerikanizirati?“, Politička misao, Zagreb, 2004.

Pađen, Ivan, „Katolicizam i nacionalizam u Hrvata 1990-ih: pravnoteorijski pogled“ (II), Liberalizam i katolicizam u Hrvatskoj - II. dio, Friedrich - Naumann - Stiftung, 1999. g., str. 139-242.

Papa Benedikt XVI., „Caritas in veritate“, Kršćanska sadašnjost, Zagreb, 2010.

Pažanin, Ante, „Pravednost i civilno društvo“, Politička misao, 40, 2003., 2, str. 3-20.

Pena Ruiz, Henri, „Što je laičnost““, Politička kultura, Zagreb, 2004.

Pera, Marcello, Zašto se trebamo zvati kršćanima, Liberalizam - Europa - Etika, Verbum, Split, 2009.

Perišić, Jure, „Balkansko u dinarskome mentalitetu: teološko viđenje dinarskog 
utjecaja na konstituiranje suvremene hrvatske države“, Obnovljeni život, 2016., 71, 1, str. 103-118.

Polić, Milan, „Odgoj i pluralizam“, Filozofska istraživanja, 101, 26 (2006.) 1, str. 2736.

Pranjić, Marko, „PAIDEIA, Starogrčka odgojno-obrazovna forma“, Metodički ogledi, 16, 1 - 2, 2009., str. 9-21.

Raguž, Ivica, „Poslanje Crkve u pluralizmu - 'preobražavajuće prihvaćanje”“,

Bogoslovska smotra 73, 2003., 2. - 3., str. 269-292.

Ratzinger, Joseph, „Uvod u kršćanstvo“, Kršćanska sadašnjost, Zagreb, 2007.

Ratzinger, Joseph - Bertone, Tarcisio, Doctrinal note on some questions regarding the participation of Catholics in political life, 2003.,

http://www.ewtn.com/library/curia/cdfpolif.htm, 2. ožujka 2010.

Reese-Schafer, Walter, „Civilno društvo i demokracija“, Politička misao, 41, 2004., 3, str. 65-79.

Rodin, Davor, „Zakašnjela sekularizacija“, Politička misao, 44, 2007., 1, str. 1-13.

Sesardić, Neven, „Homoseksualni brak: pobjeda loših argumenata“, Prolegomena, 6 (1) 2007., str. 5-28.

Skledar, Nikola, „Religijske promjene i vrijednosti“, Sociologija sela, 38 (2000.) 1/2 (147/148), str. 13-20.

Stala, Josef, 2015., „Punina postojanja osobe - civilizacija ljubavi u kontekstu postmoderne“, u: Zbornik radova XX. međunarodnog teološkog simpozija Laička država - Religija - Crkva: od ideologizirane neutralnosti do prostoradijaloškog suživota, Crkva u svijetu, 50, 3, str. 469-477.

Staničić, Frane, 2014., „The legal status of religious communities in Croatian law“,

Zbornik PFZ, 64 (2), str. 225-254.

Špehar, Hrvoje, ,Prototipski slučaj francuskog modela laičke republike. Da li je ‘izvoziv’ unutar EU?“, Godišnjak, Univerzitet Beograd (FPN), 3/3, 2009., str. 273-289, http://www. fpn.bg.ac.rs/wp-content/uploads/2010/05/godisnjak_2008.pdf, 9. srpnja 2011.

Špehar, Hrvoje, „Europeizacija i eurolaicizacija: ključne prekretnice u odnosima

Europske unije i crkava, religijskih zajednica i nekonfesionalnih organizacija“, Anali Hrvatskog politološkog društva, 6, 2009., str. 51-65.

Špehar, Hrvoje, „Historijski razvoj odnosa Crkve i Države u V. Britaniji: ključne prekretnice i metamorfoze 'državne crkve' u multikulturalnom društvu“, Anali hrvatskog politološkog društva, 7 (1), 2010., str. 171-192.

Špehar, Hrvoje, „Laičnost: etimologija i historijat“, Politička misao, (48) 1, 2011., str. 108-134.

Šimić, Josip, „Religije i crkve pred izazovom globalizacije“, Filozofska istraživanja, 116, 29 (2009.), 4, str. 745-761. 
Tanjić, Željko, „Podijeljenosti u hrvatskom društvu: mogući uzroci i posljedice u

perspektivi Ivana Rogića i Željka Mardešića“, Bogoslovska smotra, 87 (2017.), 3, str. 659-673.

Thoreau, Henry David, „Građanska neposlušnost“, Diskrepancija, 4, 7/8, (2003.),

http://www.diskrepancija.org/casopis/index.php?id=56,70,0,0,1,0, 19. siječnja

2009.

Torfs, Rik, „Religion and State Relationships in Europe“, Religious Studies Review, 1, 4, 2007., str. 31-41.

Ustav Republike Hrvatske, Narodne novine, IX izdanje, Zagreb, 2005.

Ugovori Svete Stolice i Republike Hrvatske, Glas Koncila, Zagreb, 2001.

Ugovor Svete Stolice i RH o gospodarskim pitanjima

Ugovor Svete Stolice i RH o pravnim pitanjima

Ugovor Svete Stolice i RH o suradnji na području odgoja i kulture

Uzelac, Alan, „Od liberalizma do katolicizma: neki aspekti reguliranja pravnih odnosa crkve i države u RH - novo pravno uređenje braka“, Liberalizam i katolicizam u Hrvatskoj - II. dio, Friedrich - Naumann - Stiftung, 1999., str. 243-293.

Vrcan, Srđan, „Europski identitet - neke ključne dileme“, Revija za sociologiju, 36, 2005., 1 - 2, str. 7-21.

Vujadinović, Dragica „Civilno društvo i politička kultura“, Filozofska istraživanja, (28) 1, 2008., str. 21-33.

Zovkić, Mato, „Katoličko gledanje na religije u zemljama tranzicije“, Zbornik radova: Religija i sekularna država, Međureligijski institut u BiH, Sarajevo, 2007., str. 37-48.

Zrinščak, Siniša, „Religija, Crkva i treći sektor u Srednjoj i Istočnoj Europi“, Revija za socijalnu politiku, 2(4): 1995, str. 305-314.

Zrinščak, Siniša, „Religija i hrvatsko društvo“, Društvena istraživanja, 1998., 3 (35), str. 339-357.

Zrniščak, Siniša - Črpić, Gordan - Kušar, Stjepan, ,,Vjerovanje i religioznost“",

Bogoslovska smotra, 70, 2, 2000., str. 233-255.

Zrinščak, Siniša, , Religija, civilno društvo, socijalni problemi““, Društvena istraživanja, 75-76 (1-2), 2005., str. 71-96.

Zrinščak, Siniša, ,Što je religija i čemu religija: sociološki pristup“, Bogoslovna smotra, 78, 2008., str. 25-37. 


\section{ETHICS - CIVIL RIGHT DISPUTE AND LEGAL POSITION OF RELIGIOUS COMMUNITIES IN PLURALISTIC SOCIETIES}

This paper is about the relation between constitutional orientations with state contract and religious communities through the thesis of: a state which by its constitution protects social plurality, freedom of beliefs and citizen consciousness and which from its institutions and authority separates religious communities and should not contract with them a model of cooperation which damages or yields a part of constitutionally guaranteed rights. By initiating public debate, an attempt is made to contribute to explain how (un)founded the dilemma is on the possible destruction of human rights caused by exceeding constitution with the legal position of religious communities. The paradox is if the state contract and religious communities destroy human ethics and secular direction because interpretation of one ethic doctrine of human personality opens up several possibilities of legal involution of parts of fundamental and citizen rights. Such a contract points out the incompatibility of constitution with the utilitarianism of co-administrative non-confrontation.

Key words: (de) etatization, state / local public sphere, secularism, generally useful/less), private public sphere, subsidiarity, synergy, freedom of choice 